\title{
A carbazole-derived nitroxide that is an analogue of cytidine - a rigid spin label for DNA and RNA
}

\author{
Anna-Lena Johanna Segler ${ }^{1}$ and Snorri Th. Sigurdsson ${ }^{1^{*}}$ \\ ${ }^{1}$ University of Iceland, Department of Chemistry, Science Institute, Dunhaga 3, 107 Reykjavik, \\ Iceland. \\ *Email: snorrisi@hi.is
}

Table of Contents

Analysis of spin-labeled oligonucleotides by MS and EPR spectroscopy

Table S1. Monoisotopic masses of modified oligonucleotides and spin-labeling efficiency of spin-labeled oligonucleotides. Y stands for nucleoside 25.

Crystallographic data

Table S2. Crystal data.

UV-vis analysis of $\dot{\mathbf{C}}$ and $\dot{\mathbf{C}} \mathbf{m}$ and their extinction coefficients.

Table S3. The molar extinction coefficients $(\varepsilon)$ of nitroxides $\dot{\mathbf{C}}$ and $\dot{\mathbf{C}} \mathbf{m}$ at various wavelengths in $\mathrm{H}_{2} \mathrm{O}$.

UV-vis absorption spectrum of $\dot{\mathbf{C}}$

Figure S1. UV-vis absorption spectrum of $\dot{\mathbf{C}}$. $\dot{\mathbf{C}}$ and $\dot{\mathbf{C}} \mathrm{m}$ have identical spectra and therefore, only one of their spectra is shown.

${ }^{1} \mathrm{H}-,{ }^{13} \mathrm{C}$ - and ${ }^{31} \mathrm{P}-\mathrm{NMR}$ spectra

Figure S2. ${ }^{1} \mathrm{H}-\mathrm{NMR}$ spectrum of 3 in $\mathrm{CDCl}_{3}$ at $400 \mathrm{MHz}$.

Figure S3. ${ }^{13} \mathrm{C}\left\{{ }^{1} \mathrm{H}\right\}-\mathrm{NMR}$ spectrum of 3 in $\mathrm{CDCl}_{3}$ at $101 \mathrm{MHz}$.

Figure S4. ${ }^{1} \mathrm{H}-\mathrm{NMR}$ spectrum of 4 in $\mathrm{CDCl}_{3}$ at $400 \mathrm{MHz}$.

Figure S5. ${ }^{13} \mathrm{C}\left\{{ }^{1} \mathrm{H}\right\}-\mathrm{NMR}$ spectrum of 4 in $\mathrm{CDCl}_{3}$ at $101 \mathrm{MHz}$.

Figure S6. ${ }^{1} \mathrm{H}-\mathrm{NMR}$ spectrum of 5 in $\mathrm{CDCl}_{3}$ at $400 \mathrm{MHz}$.

Figure S7. ${ }^{13} \mathrm{C}\left\{{ }^{1} \mathrm{H}\right\}-\mathrm{NMR}$ spectrum of 5 in $\mathrm{CDCl}_{3}$ at $101 \mathrm{MHz}$.

Figure S8. ${ }^{1} \mathrm{H}-\mathrm{NMR}$ spectrum of 6 in $\mathrm{CDCl}_{3}$ at $400 \mathrm{MHz}$.

Figure 59. ${ }^{13} \mathrm{C}\left\{{ }^{1} \mathrm{H}\right\}-\mathrm{NMR}$ spectrum of 6 in $\mathrm{CDCl}_{3}$ at $101 \mathrm{MHz}$.

Figure S10. ${ }^{1} \mathrm{H}-\mathrm{NMR}$ spectrum of 8 in $\mathrm{CDCl}_{3}$ at $400 \mathrm{MHz}$.

Figure S11. ${ }^{13} \mathrm{C}\left\{{ }^{1} \mathrm{H}\right\}-\mathrm{NMR}$ spectrum of 8 in $\mathrm{CDCl}_{3}$ at $101 \mathrm{MHz}$.

Figure S12. ${ }^{1} \mathrm{H}-\mathrm{NMR}$ spectrum of 9 in $\mathrm{CDCl}_{3}$ at $400 \mathrm{MHz}$.

Figure S13. ${ }^{13} \mathrm{C}\left\{{ }^{1} \mathrm{H}\right\}-\mathrm{NMR}$ spectrum of 9 in $\mathrm{CDCl}_{3}$ at $101 \mathrm{MHz}$. 
Figure S14. ${ }^{1} \mathrm{H}-\mathrm{NMR}$ spectrum of 10 in $\mathrm{CDCl}_{3}$ at $400 \mathrm{MHz}$.

Figure S15. ${ }^{13} \mathrm{C}\left\{{ }^{1} \mathrm{H}\right\}-\mathrm{NMR}$ spectrum of 10 in $\mathrm{CDCl}_{3}$ at $101 \mathrm{MHz}$.

Figure S16. ${ }^{1} \mathrm{H}-\mathrm{NMR}$ spectrum of 11 in $\mathrm{CDCl}_{3}$ at $400 \mathrm{MHz}$.

Figure S17. ${ }^{13} \mathrm{C}\left\{{ }^{1} \mathrm{H}\right\}-N M R$ spectrum of 11 in $\mathrm{CDCl}_{3}$ at $101 \mathrm{MHz}$.

Figure S18. ${ }^{1} \mathrm{H}-\mathrm{NMR}$ spectrum of 14 in $\mathrm{CDCl}_{3}$ at $400 \mathrm{MHz}$.

Figure S19. ${ }^{13} \mathrm{C}\left\{{ }^{1} \mathrm{H}\right\}-\mathrm{NMR}$ spectrum of 14 in $\mathrm{CDCl}_{3}$ at $101 \mathrm{MHz}$.

Figure S20. ${ }^{1} \mathrm{H}-\mathrm{NMR}$ spectrum of 15 in $\mathrm{CDCl}_{3}$ at $400 \mathrm{MHz}$.

Figure S21. ${ }^{13} \mathrm{C}\left\{{ }^{1} \mathrm{H}\right\}-\mathrm{NMR}$ spectrum of 15 in $\mathrm{CDCl}_{3}$ at $101 \mathrm{MHz}$.

Figure S22. ${ }^{1} \mathrm{H}-\mathrm{NMR}$ spectrum of 16 in $\mathrm{CDCl}_{3}$ at $400 \mathrm{MHz}$.

Figure S23. ${ }^{13} \mathrm{C}\left\{{ }^{1} \mathrm{H}\right\}-N M R$ spectrum of 16 in $\mathrm{CDCl}_{3}$ at $101 \mathrm{MHz}$.

Figure S24. ${ }^{1} \mathrm{H}-\mathrm{NMR}$ spectrum of 17 in $\mathrm{CDCl}_{3}$ at $400 \mathrm{MHz}$.

Figure S25. ${ }^{13} \mathrm{C}\left\{{ }^{1} \mathrm{H}\right\}-N M R$ spectrum of 17 in $\mathrm{CDCl}_{3}$ at $101 \mathrm{MHz}$.

Figure S26. ${ }^{1} \mathrm{H}-\mathrm{NMR}$ spectrum of 18 in $\mathrm{CDCl}_{3}$ at $400 \mathrm{MHz}$.

Figure S27. ${ }^{13} \mathrm{C}\left\{{ }^{1} \mathrm{H}\right\}-\mathrm{NMR}$ spectrum of 18 in $\mathrm{CDCl}_{3}$ at $101 \mathrm{MHz}$.

Figure S28. ${ }^{1} \mathrm{H}-\mathrm{NMR}$ spectrum of 19 in $\mathrm{CDCl}_{3}$ at $400 \mathrm{MHz}$.

Figure S29. ${ }^{13} \mathrm{C}\left\{{ }^{1} \mathrm{H}\right\}-\mathrm{NMR}$ spectrum of 19 in $\mathrm{CDCl}_{3}$ at $101 \mathrm{MHz}$.

Figure S30. ${ }^{1} \mathrm{H}-\mathrm{NMR}$ spectrum of 20 in $\mathrm{CDCl} 3$ at $400 \mathrm{MHz}$.

Figure S31. ${ }^{13} \mathrm{C}\{1 \mathrm{H}\}-\mathrm{NMR}$ spectrum of 20 in $\mathrm{CDCl}_{3}$ at $101 \mathrm{MHz}$.

Figure S32. ${ }^{31} \mathrm{P}-\mathrm{NMR}$ spectrum of 20 in $\mathrm{CDCl}_{3}$ at $162 \mathrm{MHz}$.

Figure S33. ${ }^{1} \mathrm{H}-\mathrm{NMR}$ spectrum of 21 in $\mathrm{CDCl}_{3}$ at $400 \mathrm{MHz}$.

Figure S34. ${ }^{13} \mathrm{C}\left\{{ }^{1} \mathrm{H}\right\}-\mathrm{NMR}$ spectrum of 21 in $\mathrm{CDCl}_{3}$ at $101 \mathrm{MHz}$.

Figure S35. ${ }^{31} \mathrm{P}-\mathrm{NMR}$ spectrum of 21 in $\mathrm{CDCl}_{3}$ at $162 \mathrm{MHz}$.

Figure S36. ${ }^{1} \mathrm{H}-\mathrm{NMR}$ spectrum of 22 in $\mathrm{CDCl}_{3}$ at $400 \mathrm{MHz}$.

Figure S37. ${ }^{13} \mathrm{C}\left\{{ }^{1} \mathrm{H}\right\}-\mathrm{NMR}$ spectrum of 22 in $\mathrm{CDCl}_{3}$ at $101 \mathrm{MHz}$.

Figure S38. ${ }^{1} \mathrm{H}-\mathrm{NMR}$ spectrum of 23 in $\mathrm{CDCl}_{3}$ at $400 \mathrm{MHz}$.

Figure S39. ${ }^{13} \mathrm{C}\left\{{ }^{1} \mathrm{H}\right\}-N M R$ spectrum of 23 in $\mathrm{CDCl}_{3}$ at $101 \mathrm{MHz}$.

Figure S40. ${ }^{1} \mathrm{H}-\mathrm{NMR}$ spectrum of 24 in $\mathrm{CDCl}_{3}$ at $400 \mathrm{MHz}$.

Figure S41. ${ }^{13} \mathrm{C}\left\{{ }^{1} \mathrm{H}\right\}-\mathrm{NMR}$ spectrum of 24 in $\mathrm{CDCl}_{3}$ at $101 \mathrm{MHz}$.

Figure S42. ${ }^{1} \mathrm{H}-\mathrm{NMR}$ spectrum of 25 in DMSO- $d_{6}$ at $400 \mathrm{MHz}$.

Figure S43. ${ }^{13} \mathrm{C}\left\{{ }^{1} \mathrm{H}\right\}-\mathrm{NMR}$ spectrum of 25 in DMSO- $d_{6}$ at $101 \mathrm{MHz}$. S27

Figure S44. ${ }^{1} \mathrm{H}-\mathrm{NMR}$ spectrum of 26 in $\mathrm{CDCl}_{3}$ at $400 \mathrm{MHz}$. S28

Figure S45. ${ }^{13} \mathrm{C}\left\{{ }^{1} \mathrm{H}\right\}-\mathrm{NMR}$ spectrum of 26 in $\mathrm{CDCl}_{3}$ at $101 \mathrm{MHz}$. S28

Figure S46. ${ }^{1} \mathrm{H}-\mathrm{NMR}$ spectrum of 27 in $\mathrm{CDCl}_{3}$ at $400 \mathrm{MHz}$. S29

Figure S47. ${ }^{13} \mathrm{C}\left\{{ }^{1} \mathrm{H}\right\}-\mathrm{NMR}$ spectrum of 27 in $\mathrm{CDCl}_{3}$ at $101 \mathrm{MHz}$. S29 
Figure S48. ${ }^{31} \mathrm{P}-\mathrm{NMR}$ spectrum of 27 in $\mathrm{CDCl}_{3}$ at $162 \mathrm{MHz}$.

Models of $\dot{\mathbf{C}}$-labeled DNA and $\dot{\mathbf{C}} \mathrm{m}$-labeled RNA

Figure S49. Space-filling models of $\dot{\mathbf{C}}$ - and $\dot{\mathbf{C}} \mathbf{m}$-labeled oligonucleotide duplexes. A. B-form DNA duplex with $\dot{C}$ projected into the major groove. B. A-form RNA duplex containing $\dot{\mathbf{C}}$. S31

CW-EPR spectra of spin-labeled oligonucleotides

Figure S50. EPR spectra of spin-labeled oligonucleotides.

HPLC analyses of enzymatic digests

Figure S51. HPLC chromatograms of DNA oligonucleotides after enzymatic digestion with snake venom phosphodiesterase, nuclease P1, and alkaline phosphatase.

Figure S52. HPLC chromatograms of RNA oligonucleotides after enzymatic digestion with snake venom phosphodiesterase, nuclease P1, and alkaline phosphatase.

Thermal denaturation curves of spin-labeled oligonucleotide duplexes

Figure S53. Thermal denaturing analysis of duplexes A, B, C, D (A); E, F (B); G, H (C); I, J (D); K, $\mathrm{L}(\mathrm{E})$.

CD spectra of oligonucleotide duplexes

Figure S54. CD spectra of duplexes A, B, C, D (A); E, F (B); G, H (C); I, J (D); K, L (E). 
Analysis of spin-labeled oligonucleotides by MS and EPR spectroscopy. The incorporation of $\dot{\mathbf{C}}$ and $\dot{\mathbf{C}} \mathbf{m}$ into oligonucleotides (Table S1) was confirmed by MALDI-TOF analysis; their calculated and observed monoisotopic masses are listed in Table S1. The amount of radical in each oligonucleotide was determined by spin counting using EPR spectroscopy ${ }^{1}$ (Table S1).

Table S1. Monoisotopic masses of modified oligonucleotides and spin-labeling efficiency of spin-labeled oligonucleotides. Y stands for nucleoside 25.

\begin{tabular}{|c|c|c|c|c|}
\hline & Sequence & (calcd.) & (found) & Radical (\%) \\
\hline I & 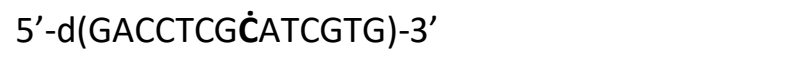 & 4424.83 & 4425.84 & 100 \\
\hline II & 5'-d(GAĆCTCGCATCGTG)-3' & 4424.83 & 4426.63 & 97 \\
\hline III & $5^{\prime}-\mathrm{d}(\dot{\mathbf{C}} A C G A T G C G A G G T C)-3^{\prime}$ & 4473.85 & 4474.58 & 95 \\
\hline IV & $5^{\prime}$-d(GACCTCGĆATCGTG(GACCTCGCATCGTG) $\left.{ }_{2}\right)-3^{\prime}$ & 13024.22 & 13024.10 & 96 \\
\hline $\mathrm{V}$ & $5^{\prime}-d(G T \dot{A} A G T G C G C G C G C G C G A T C)-3^{\prime}$ & 6319.14 & 6321.08 & 100 \\
\hline VI & $5^{\prime}$-d(GATCGCGCGĊGCGCACTGAC)-3' & 6288.14 & 6292.53 & 96 \\
\hline VII & 5'-GACCUCGĊmAUCGUG-3' & 4620.73 & 4622.90 & 99 \\
\hline VIII & 5'-UGUĊmAGUCGCGCGCGCGCAUC-3' & 6877.02 & 6881.32 & 95 \\
\hline $\mathrm{IX}$ & 5'-UGAUGCGĊmGCGCGCGACUGAC-3' & 6940.06 & 6944.60 & 90 \\
\hline$x$ & 5'-d(GACCTCGYATCGTG)-3' & 4311.75 & 4314.30 & \\
\hline
\end{tabular}




\section{Crystallographic data}

Table S2. Crystal data.

\begin{tabular}{|c|c|c|}
\hline Crystal data & $\dot{\mathbf{C} m}$ & $\dot{\mathbf{C}}$ \\
\hline Empirical formula & $\mathrm{C}_{23} \mathrm{H}_{31} \mathrm{~N}_{4} \mathrm{O}_{7}$ & $\mathrm{C}_{21} \mathrm{H}_{25} \mathrm{~N}_{4} \mathrm{O}_{5}$ \\
\hline Color & Yellow & Yellow \\
\hline Formula weight & 475.52 & 413.45 \\
\hline Crystal size $(\mathrm{mm})$ & $0.38 \times 0.21 \times 0.18$ & $0.50 \times 0.23 \times 0.12$ \\
\hline Crystal system & Orthorhombic & Triclinic \\
\hline Space group & $P 2_{1} 2_{1} 2_{1}$ & P1 \\
\hline a $(\AA ̊)$ & $5.6483(4)$ & $8.0192(5)$ \\
\hline$b(\AA)$ & $15.7903(12)$ & $11.0816(7)$ \\
\hline$c(\AA)$ & $26.219(2)$ & $12.3628(8)$ \\
\hline$\alpha\left(^{\circ}\right)$ & 90 & $98.313(2)$ \\
\hline$\beta\left(^{\circ}\right)$ & 90 & $97.337(2)$ \\
\hline$Y\left(^{\circ}\right)$ & 90 & $106.490(2)$ \\
\hline Volume $\left(\AA^{3}\right)$ & $2338.4(3)$ & $1025.75(11)$ \\
\hline$Z$ & 2 & 2 \\
\hline$D_{\text {calc. }}\left(\mathrm{g} / \mathrm{cm}^{3}\right)$ & 1.351 & 1.339 \\
\hline$F(000)$ & 1012 & 438 \\
\hline$\mu \operatorname{MoK}_{\alpha}\left(\mathrm{mm}^{-1}\right)$ & 0.101 & 0.097 \\
\hline Temperature (K) & $150(2)$ & $150(2)$ \\
\hline 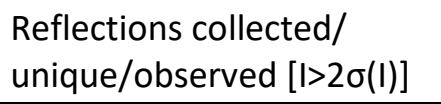 & $80870 / 9770 / 8495$ & $40344 / 12515 / 11879$ \\
\hline $\begin{array}{l}\text { Data/restraints/parameter } \\
\mathrm{s}\end{array}$ & $9770 / 0 / 329$ & $12515 / 3 / 557$ \\
\hline Goodness of fit on $\mathrm{F}^{2}$ & 1.056 & 1.031 \\
\hline Final R indices $[1>2 \sigma(I)]$ & $\begin{array}{l}R_{1}=0.0466 \\
w R_{2}=0.1199\end{array}$ & $\begin{array}{l}R_{1}=0.0329 \\
w R_{2}=0.0904\end{array}$ \\
\hline $\mathrm{R}$ indices (all data) & $\begin{array}{l}R_{1}=0.0570 \\
w R_{2}=0.1259\end{array}$ & $\begin{array}{l}R_{1}=0.0356 \\
w R_{2}=0.0924\end{array}$ \\
\hline
\end{tabular}


UV-vis analysis of $\dot{\mathbf{C}}$ and $\dot{\mathrm{C}} \mathrm{m}$ and their extinction coefficients. The extinction coefficients $(\varepsilon)$ of $\dot{\mathbf{C}}$ and $\dot{\mathbf{C}} \mathbf{m}$ (Table S3) were determined in $\mathrm{H}_{2} \mathrm{O}$ at three wavelengths $(\lambda), 325 \mathrm{~nm}, 279 \mathrm{~nm}$ and $260 \mathrm{~nm}$, using Beer's law. A series of solutions of $\dot{\mathbf{C}} / \dot{\mathbf{C}} \mathbf{m}$ was made with specific concentration (5 $\mu \mathrm{M}-100 \mu \mathrm{M})$ and the UV-vis spectra (Figure S2) of each sample were recorded. The absorption at a given $\lambda$ was plotted against the concentration of the samples resulting in a linear curve and the $\varepsilon$ was obtained from the slope of the line.

Table S3. The molar extinction coefficients $(\varepsilon)$ of nitroxides $\dot{\mathbf{C}}$ and $\dot{\mathbf{C}} \mathrm{m}$ at various wavelengths in $\mathrm{H}_{2} \mathrm{O}$.

\begin{tabular}{|c|c|c|c|}
\hline & $\varepsilon_{260 \mathrm{~nm}}(\mathrm{~L} / \mathrm{mol} \cdot \mathrm{cm})$ & $\varepsilon_{279 \mathrm{~nm}}(\mathrm{~L} / \mathrm{mol} \cdot \mathrm{cm})$ & $\varepsilon_{325 \mathrm{~nm}}(\mathrm{~L} / \mathrm{mol} \cdot \mathrm{cm})$ \\
\hline$\dot{\mathbf{C}}$ & $18400 \pm 700$ & $42800 \pm 1200$ & $8400 \pm 300$ \\
\hline$\dot{\mathbf{C}} \mathbf{m}$ & $18900 \pm 500$ & $40400 \pm 1000$ & $8600 \pm 200$ \\
\hline
\end{tabular}

\section{UV-vis absorption spectrum of $\dot{\mathbf{C}}$}

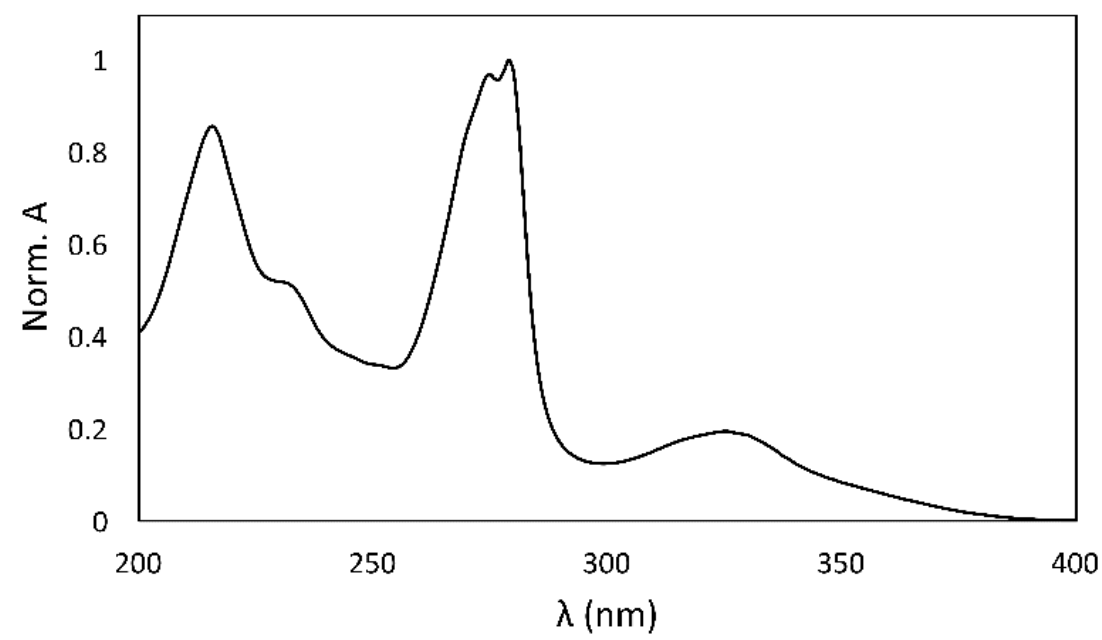

Figure S1. UV-vis absorption spectrum of $\dot{\mathbf{C}}$. $\dot{\mathbf{C}}$ and $\dot{\mathbf{C}} \mathbf{m}$ have identical spectra and therefore, only one of their spectra is shown. 
${ }^{1} \mathrm{H}-,{ }^{13} \mathrm{C}$ - and ${ }^{31} \mathrm{P}-\mathrm{NMR}$ spectra

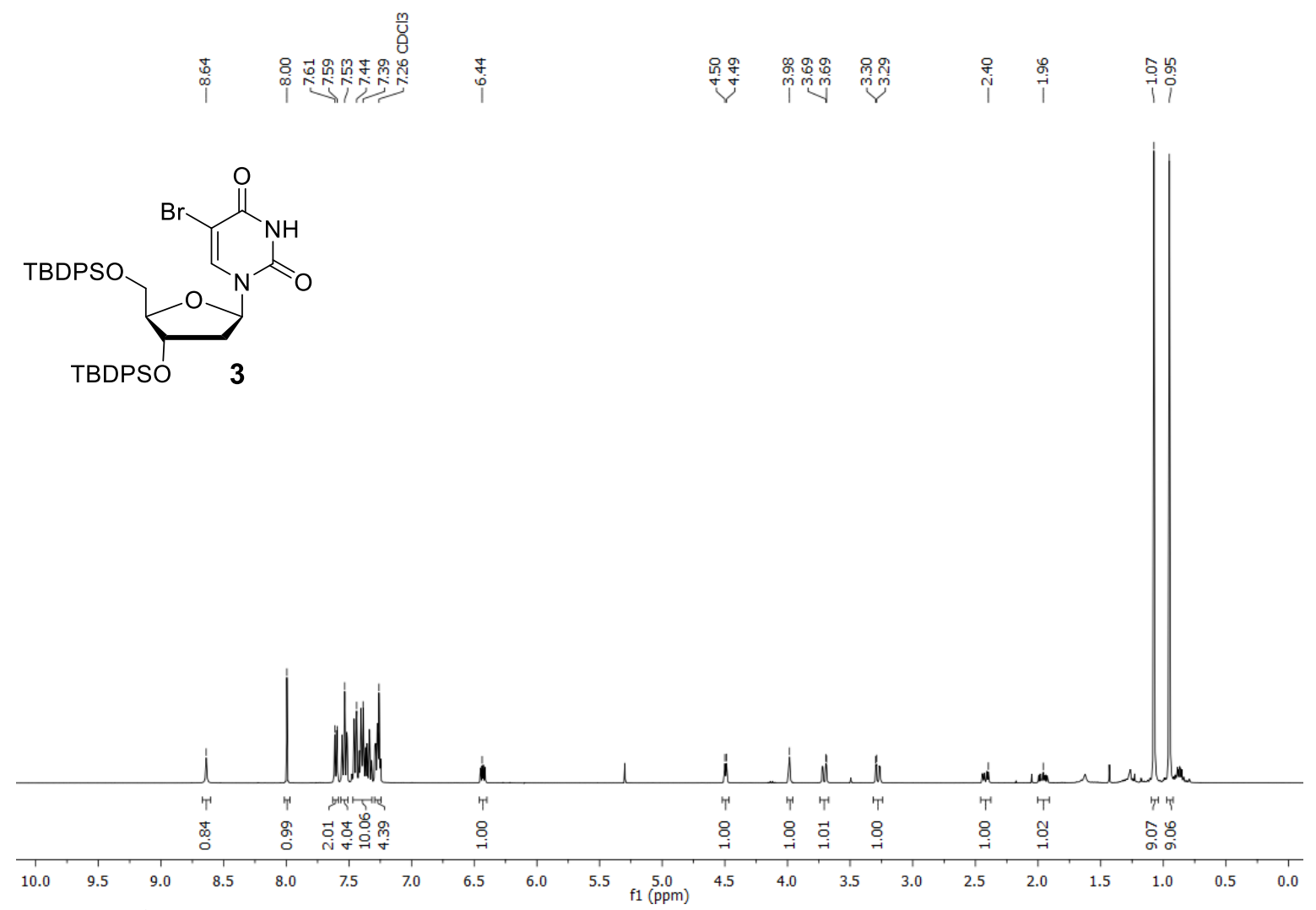

Figure S2. ${ }^{1} \mathrm{H}-\mathrm{NMR}$ spectrum of 3 in $\mathrm{CDCl}_{3}$ at $400 \mathrm{MHz}$.
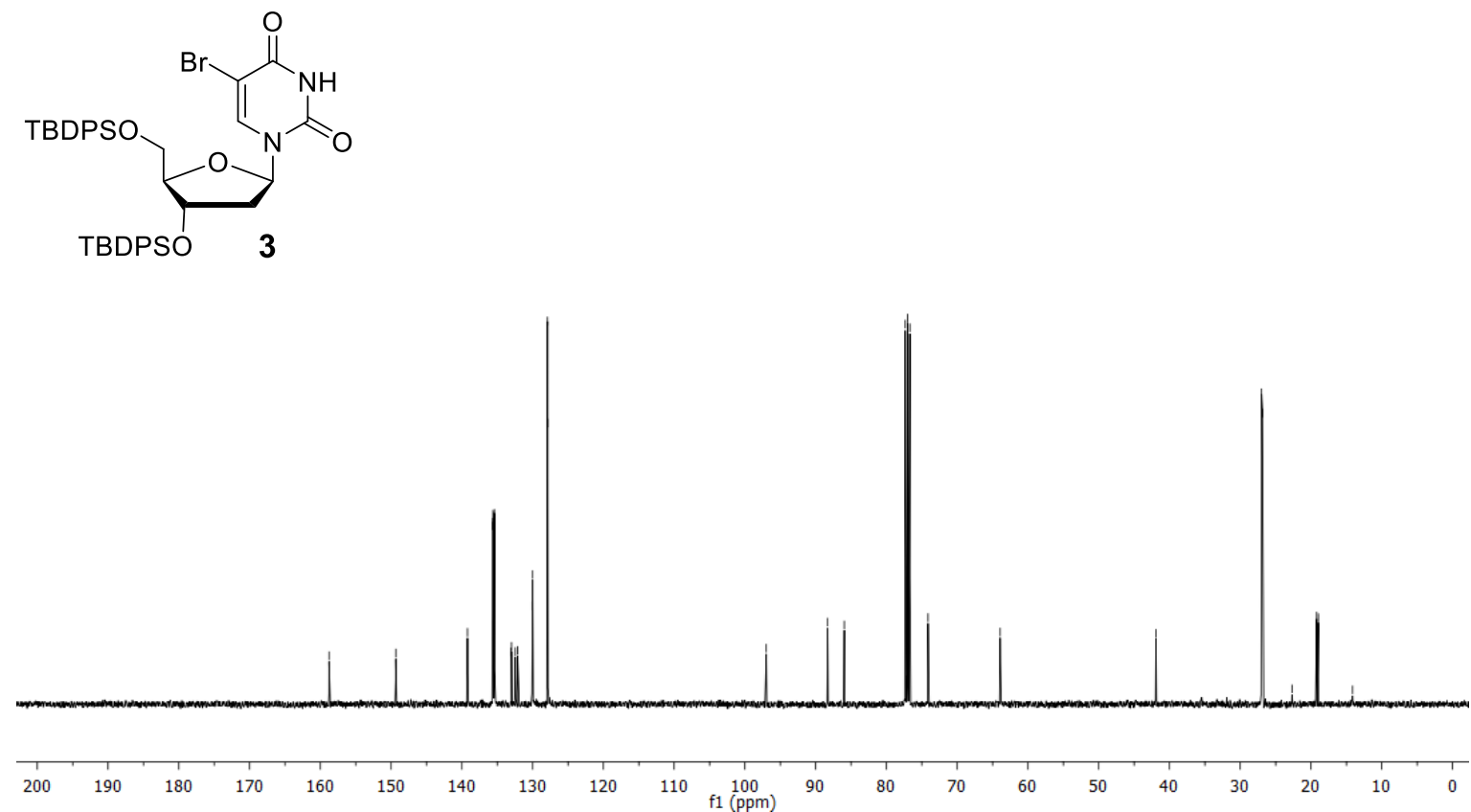

Figure S3. ${ }^{13} \mathrm{C}\left\{{ }^{1} \mathrm{H}\right\}-\mathrm{NMR}$ spectrum of $\mathbf{3}$ in $\mathrm{CDCl}_{3}$ at $101 \mathrm{MHz}$. 

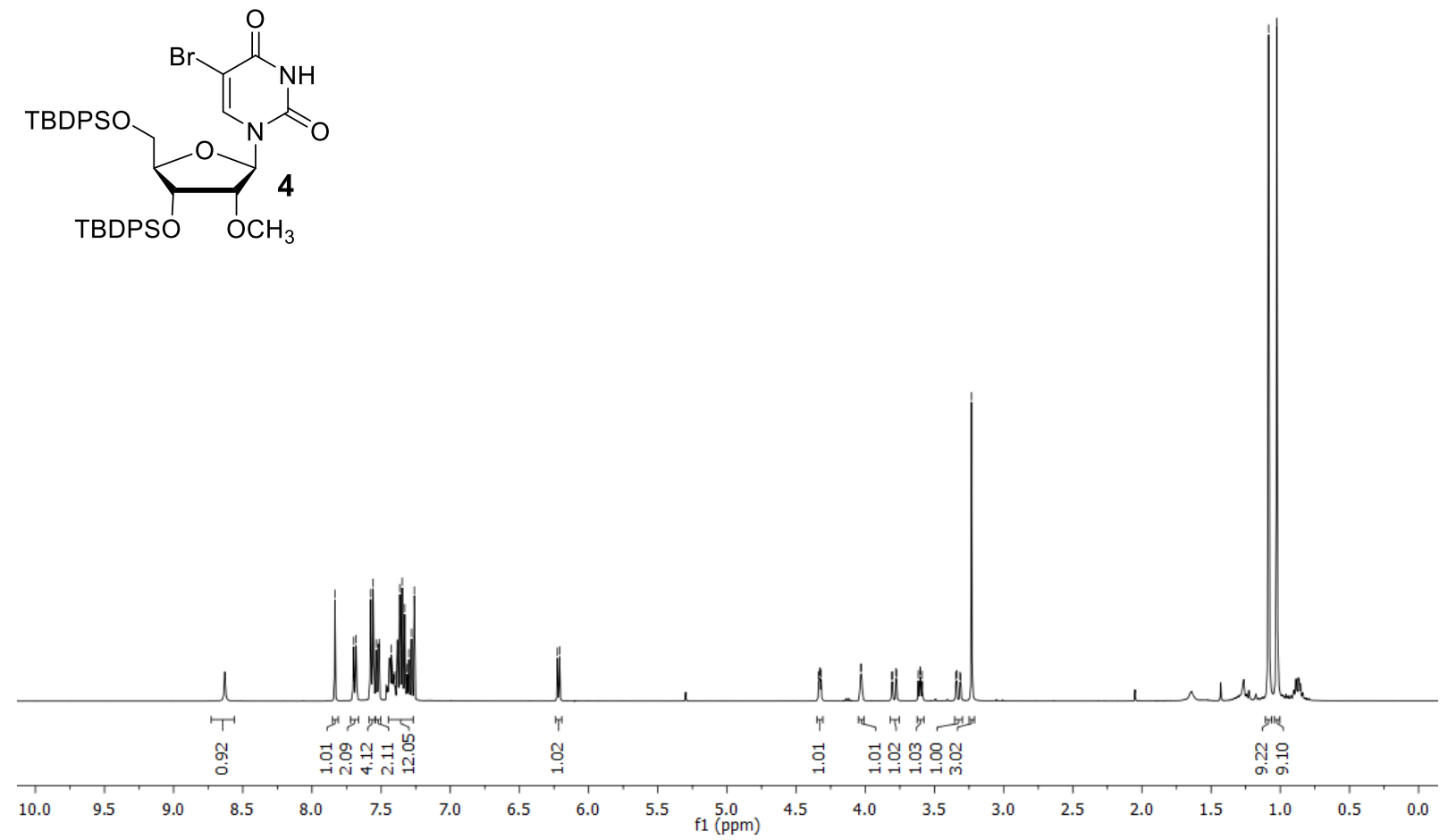

Figure S4. ${ }^{1} \mathrm{H}-\mathrm{NMR}$ spectrum of 4 in $\mathrm{CDCl}_{3}$ at $400 \mathrm{MHz}$.

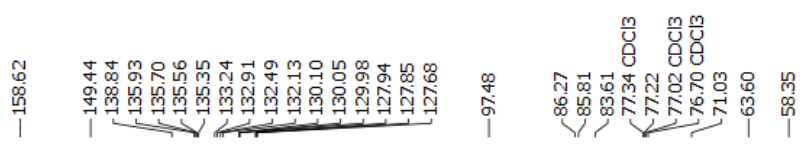

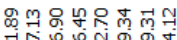

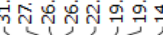
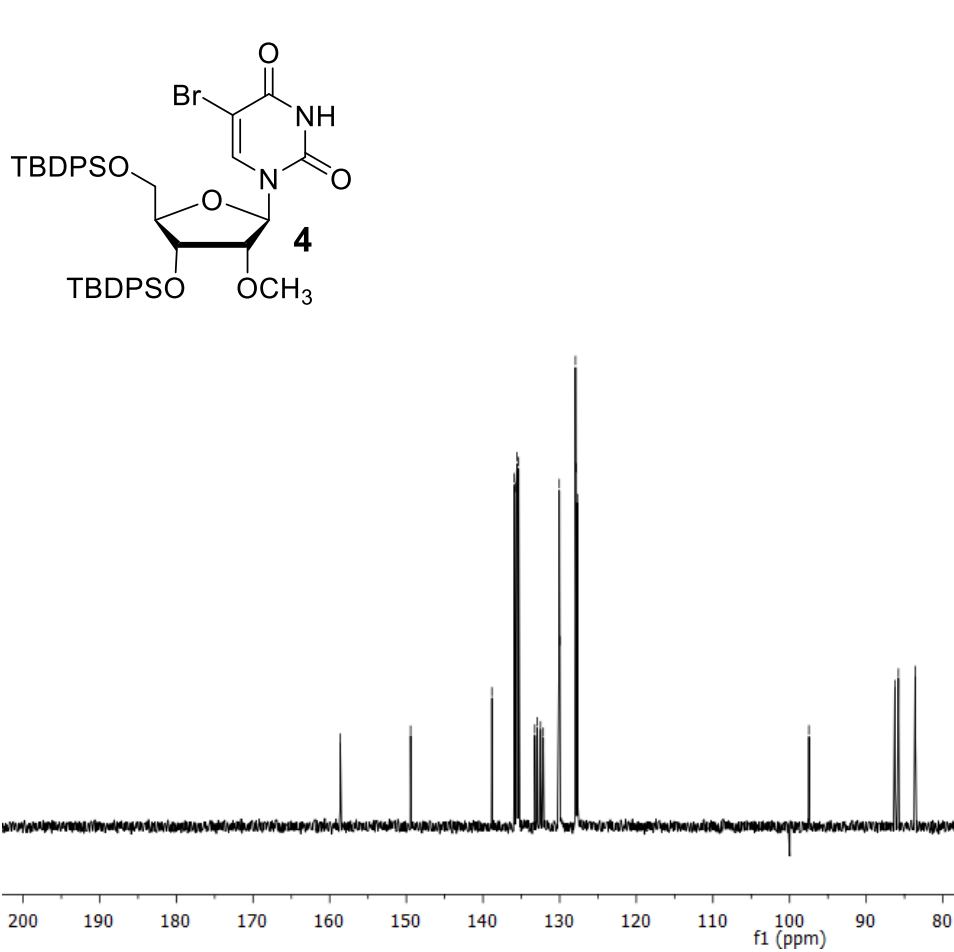

Figure S5. ${ }^{13} \mathrm{C}\left\{{ }^{1} \mathrm{H}\right\}-\mathrm{NMR}$ spectrum of 4 in $\mathrm{CDCl}_{3}$ at $101 \mathrm{MHz}$. 


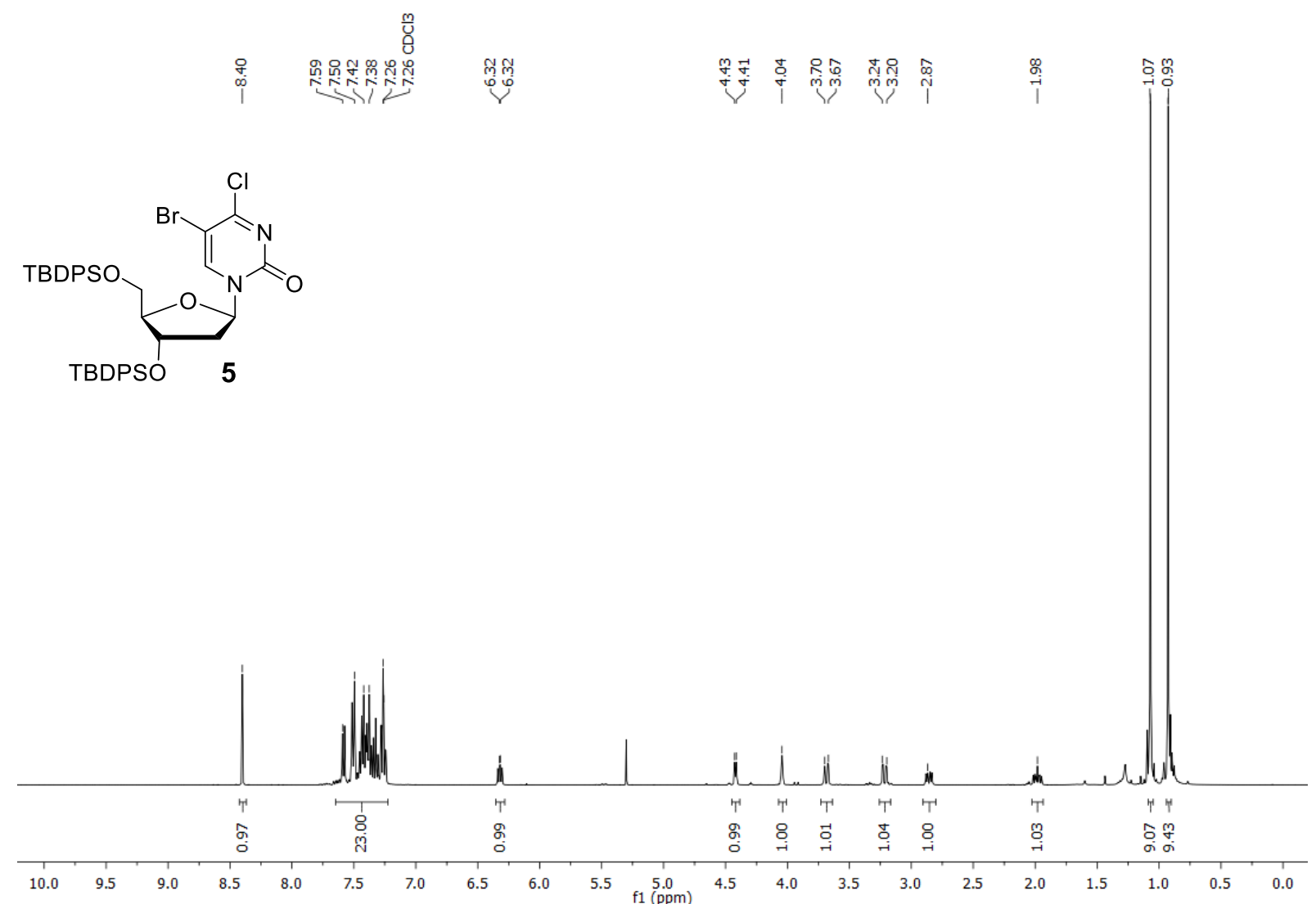

Figure S6. ${ }^{1} \mathrm{H}-\mathrm{NMR}$ spectrum of 5 in $\mathrm{CDCl}_{3}$ at $400 \mathrm{MHz}$.

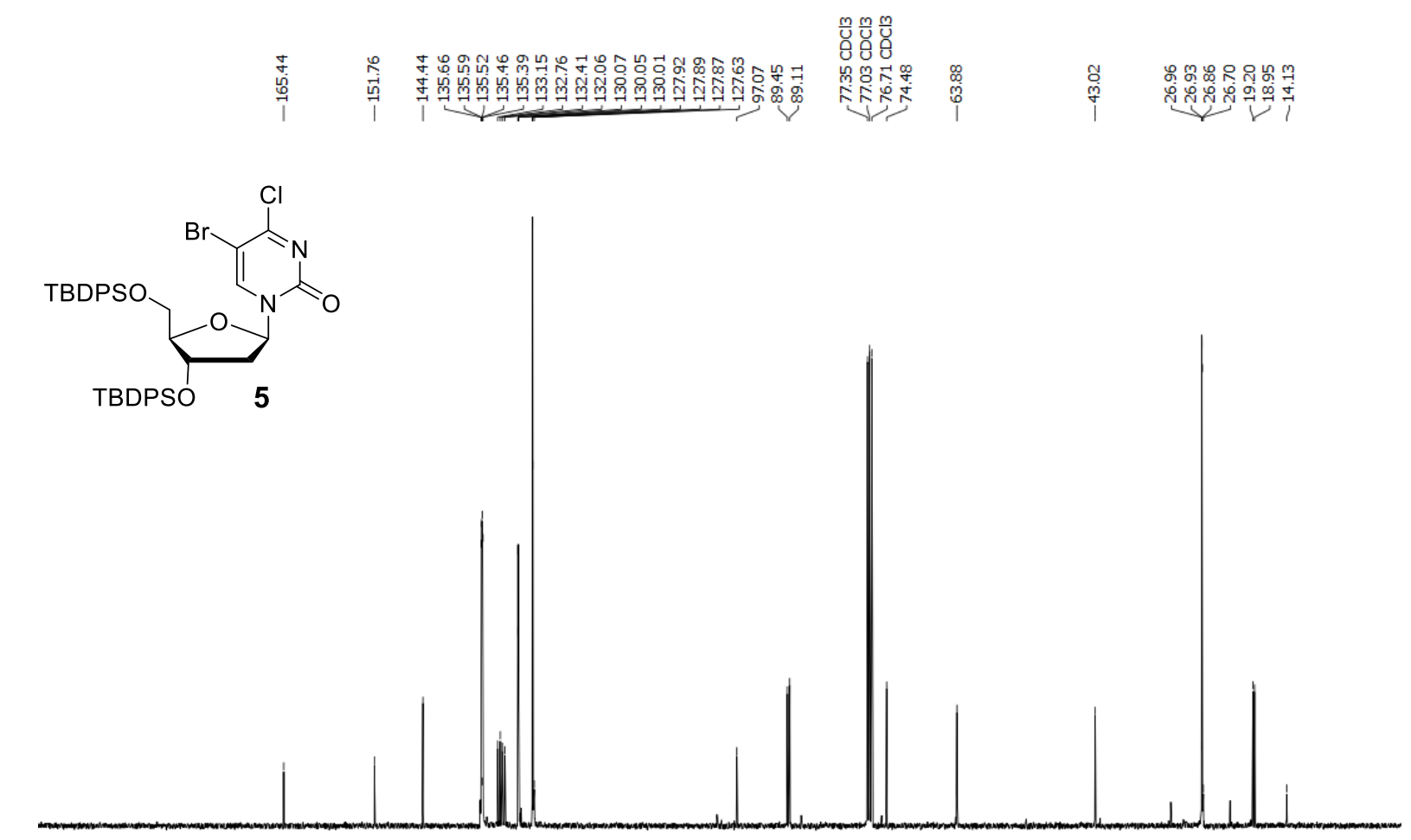

200

Figure S7. ${ }^{13} \mathrm{C}\left\{{ }^{1} \mathrm{H}\right\}$-NMR spectrum of 5 in $\mathrm{CDCl}_{3}$ at $101 \mathrm{MHz}$. 


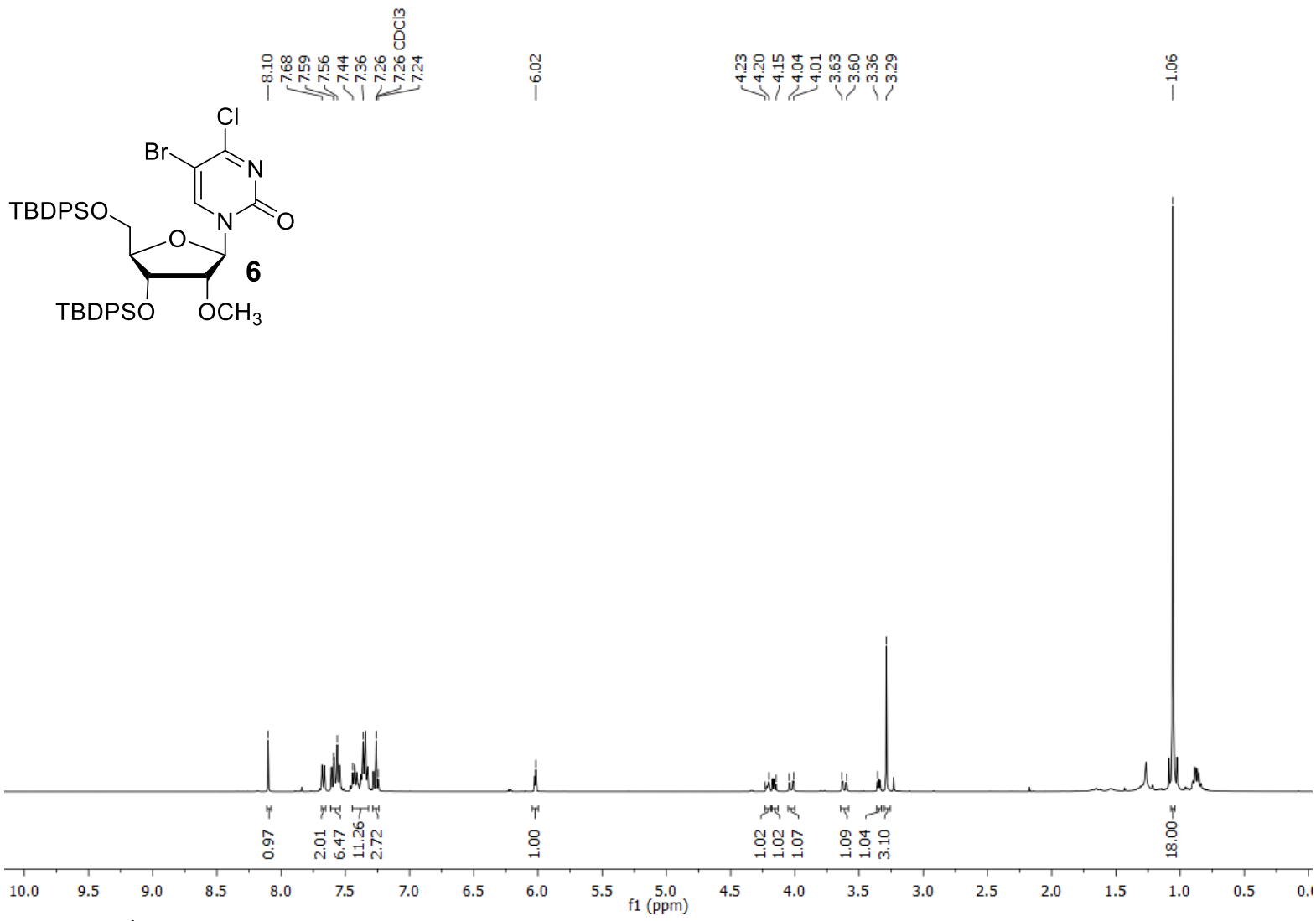

Figure S8. ${ }^{1} \mathrm{H}-\mathrm{NMR}$ spectrum of 6 in $\mathrm{CDCl}_{3}$ at $400 \mathrm{MHz}$.

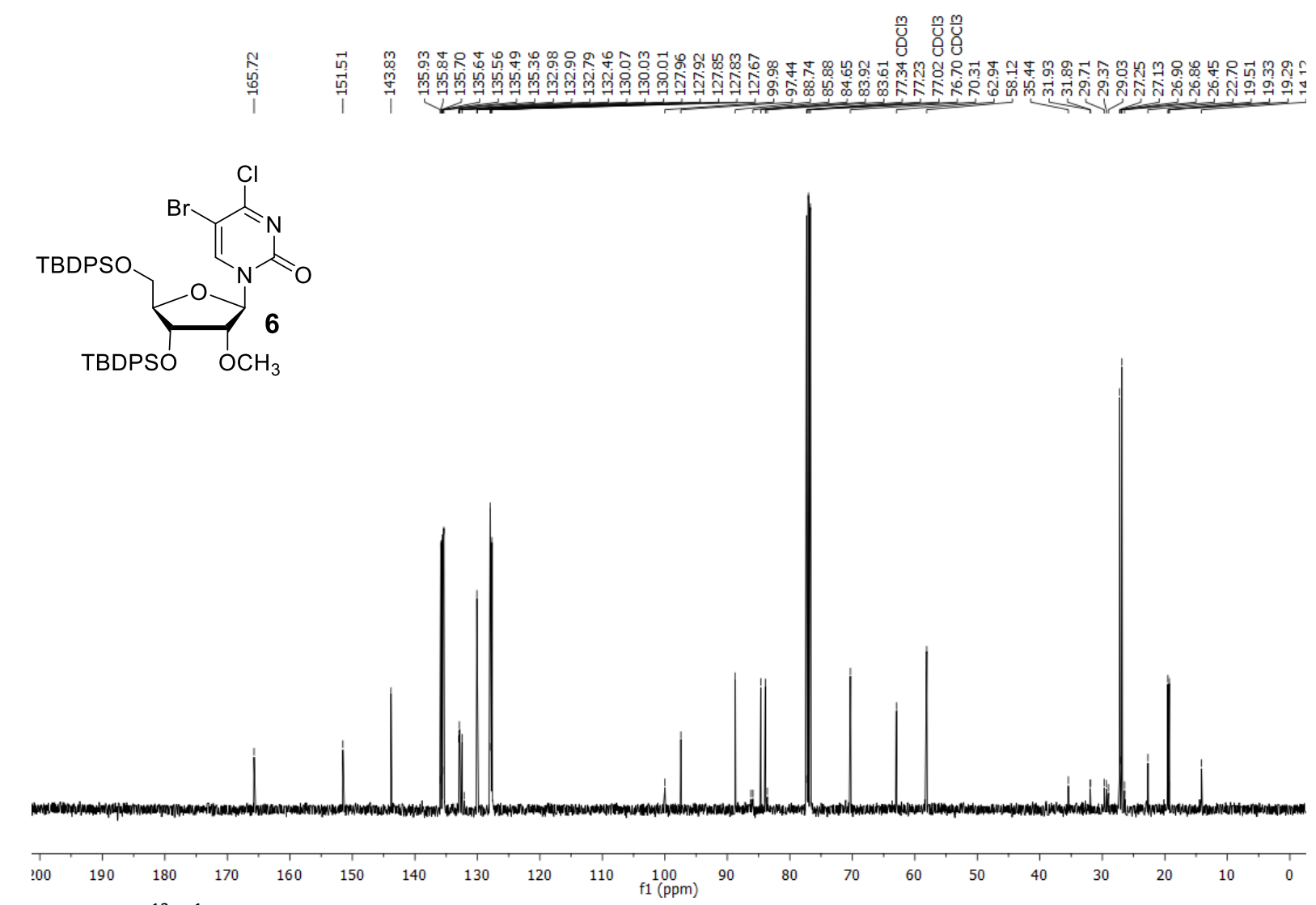

Figure S9. ${ }^{13} \mathrm{C}\left\{{ }^{1} \mathrm{H}\right\}-\mathrm{NMR}$ spectrum of 6 in $\mathrm{CDCl}_{3}$ at $101 \mathrm{MHz}$. 


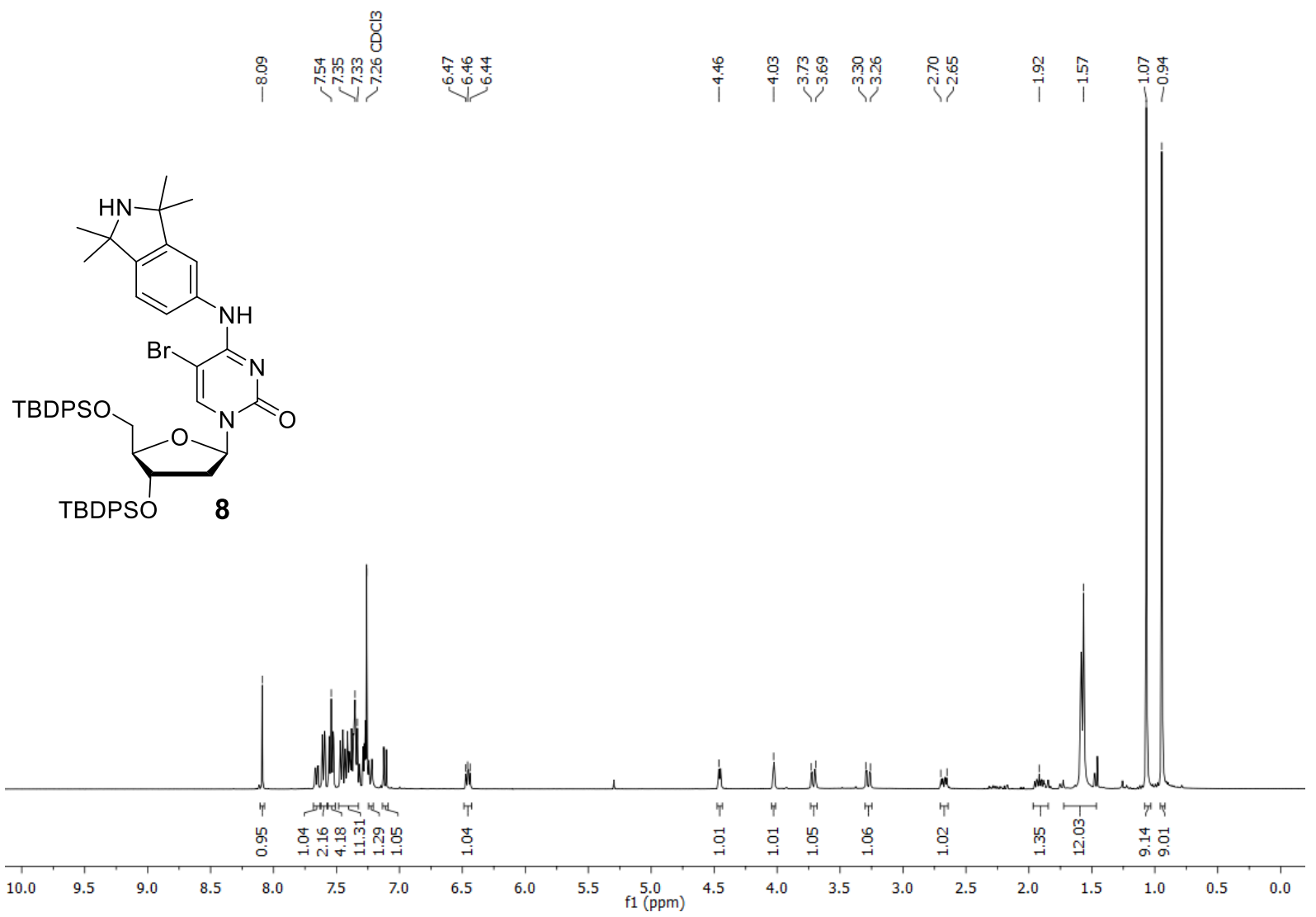

Figure S10. ${ }^{1} \mathrm{H}-\mathrm{NMR}$ spectrum of 8 in $\mathrm{CDCl}_{3}$ at $400 \mathrm{MHz}$.

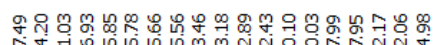

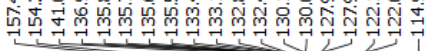
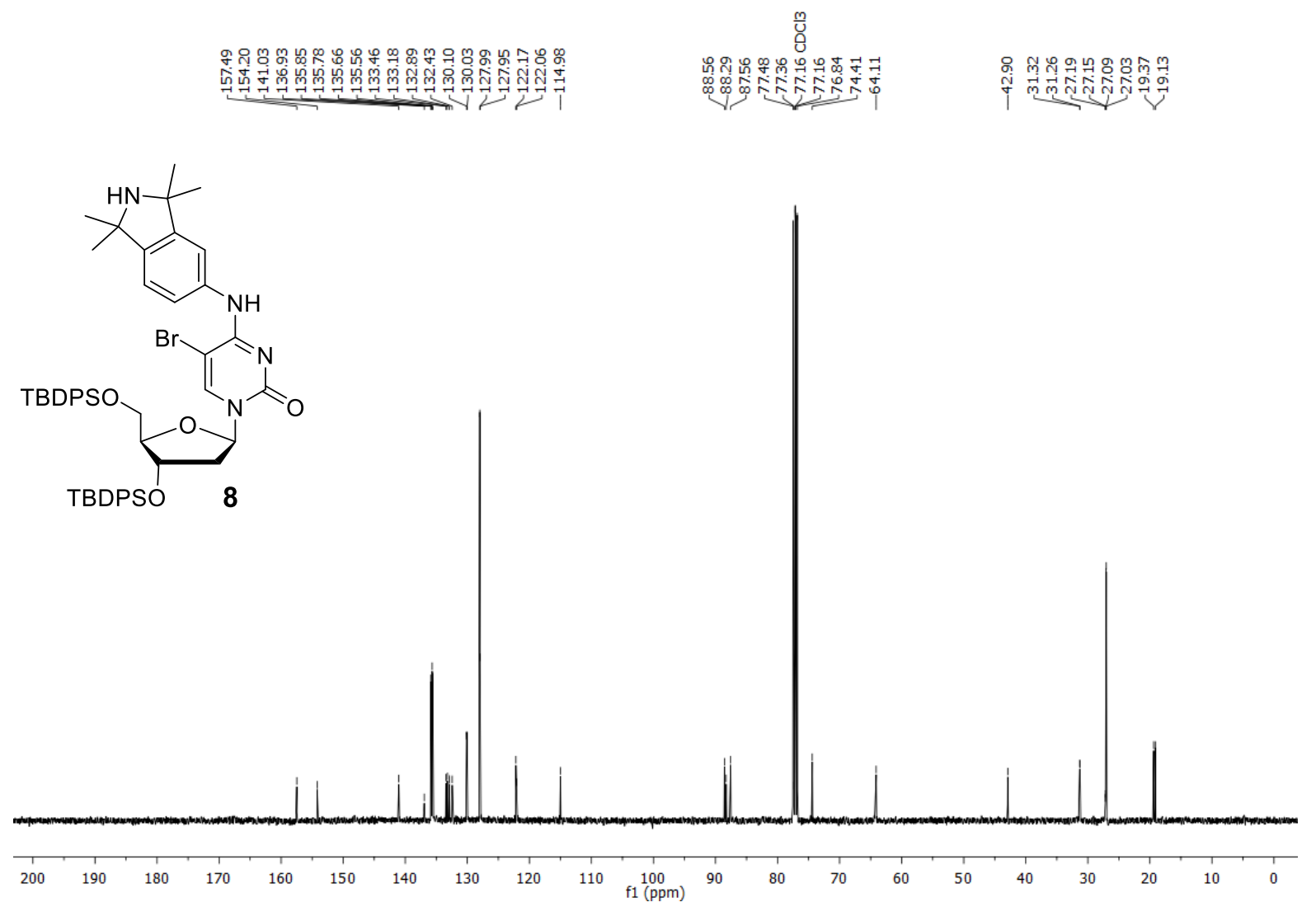

Figure S11. ${ }^{13} \mathrm{C}\left\{{ }^{1} \mathrm{H}\right\}-\mathrm{NMR}$ spectrum of 8 in $\mathrm{CDCl}_{3}$ at $101 \mathrm{MHz}$. 
응

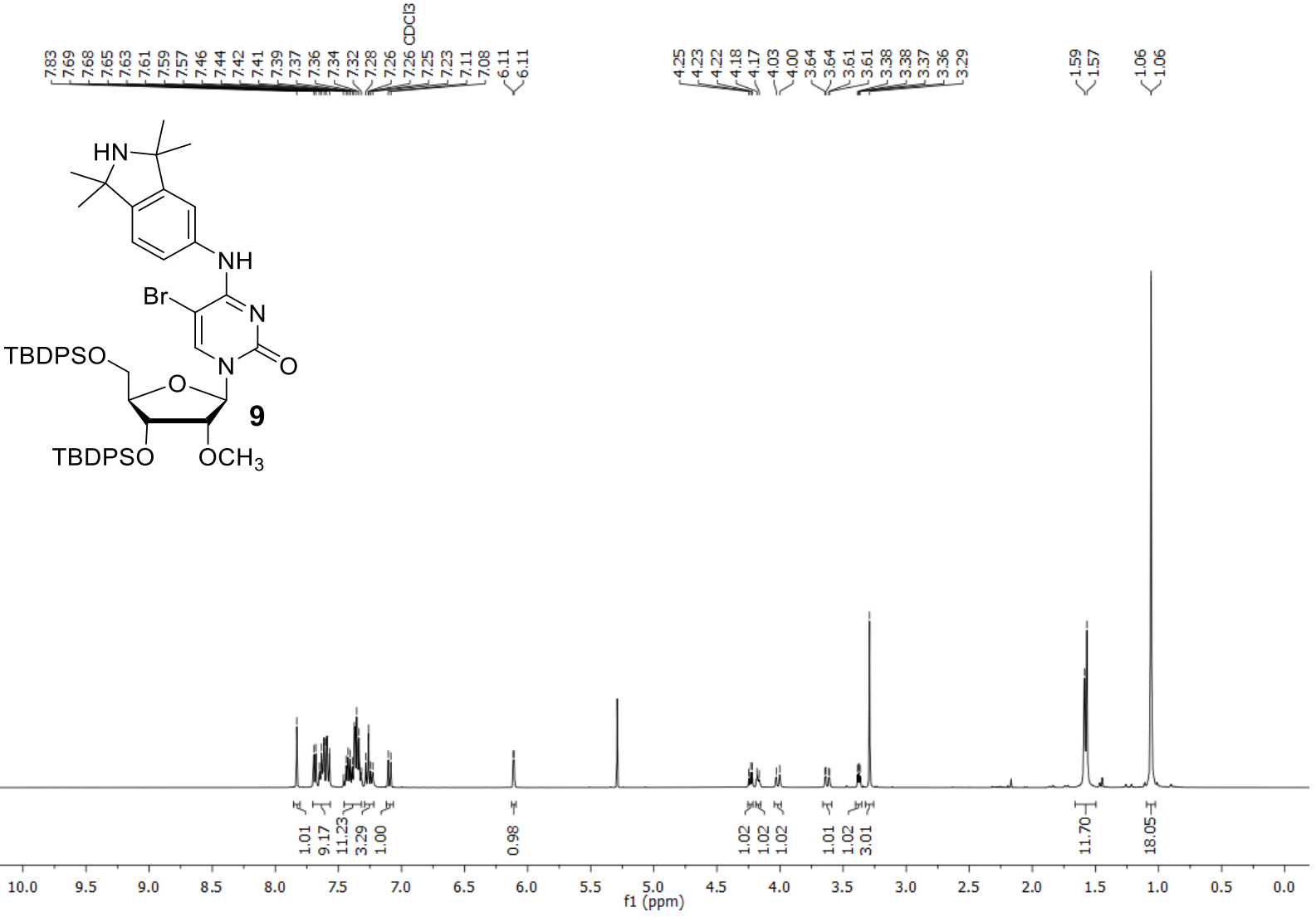

Figure S12. ${ }^{1} \mathrm{H}-\mathrm{NMR}$ spectrum of 9 in $\mathrm{CDCl}_{3}$ at $400 \mathrm{MHz}$.

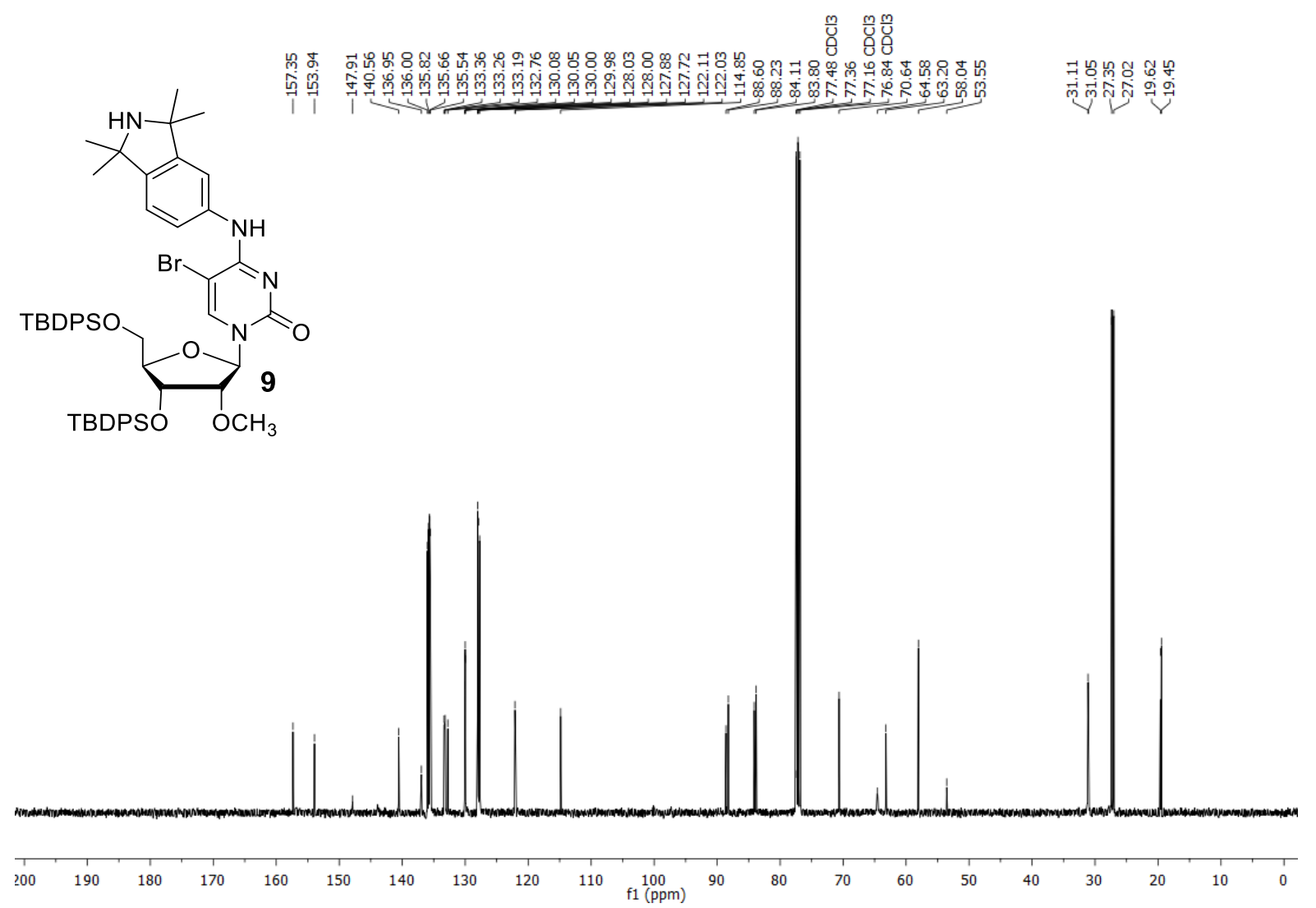

Figure S13. ${ }^{13} \mathrm{C}\left\{{ }^{1} \mathrm{H}\right\}$-NMR spectrum of 9 in $\mathrm{CDCl}_{3}$ at $101 \mathrm{MHz}$. 


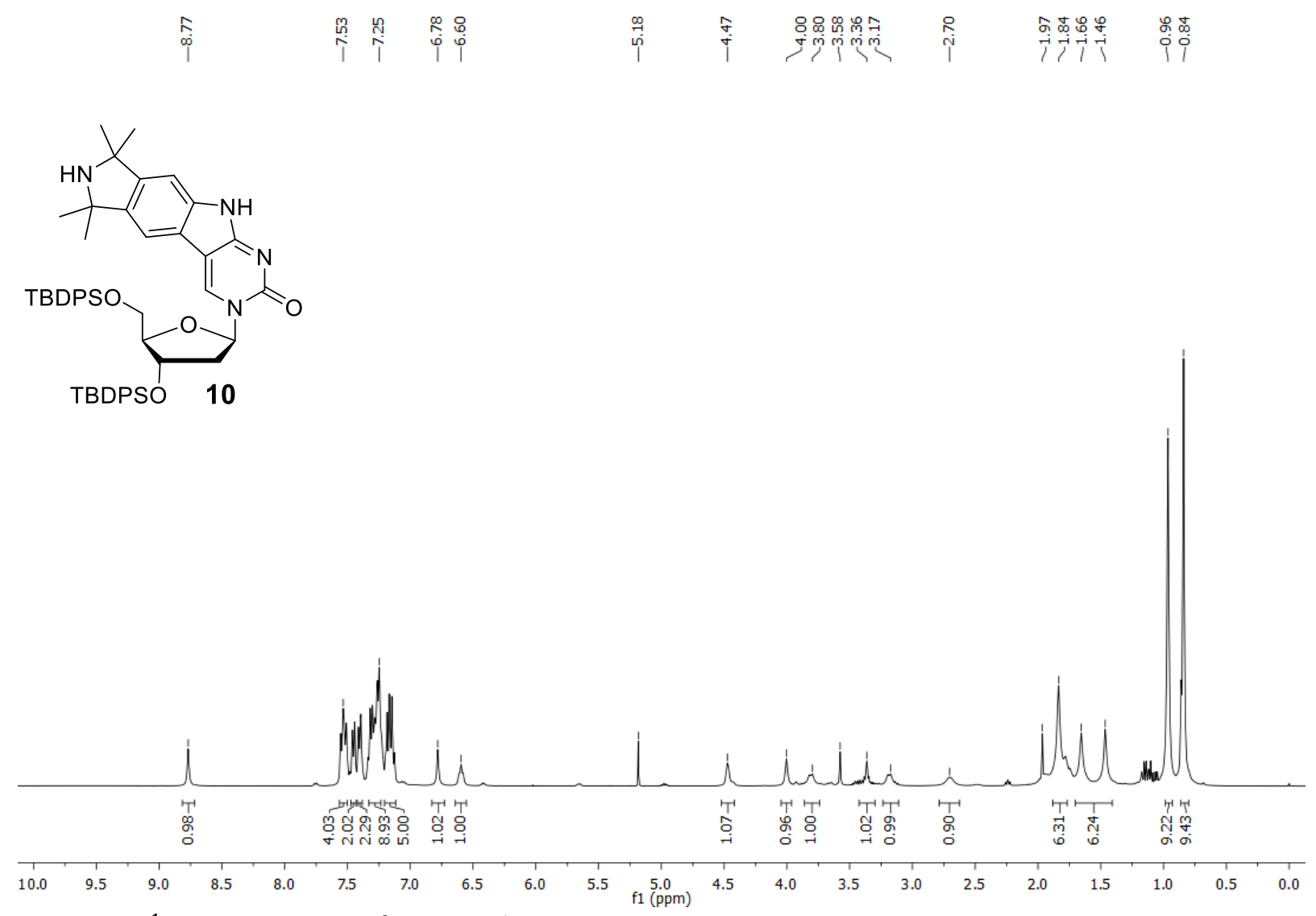

Figure S14. ${ }^{1} \mathrm{H}-\mathrm{NMR}$ spectrum of 10 in $\mathrm{CDCl}_{3}$ at $400 \mathrm{MHz}$.
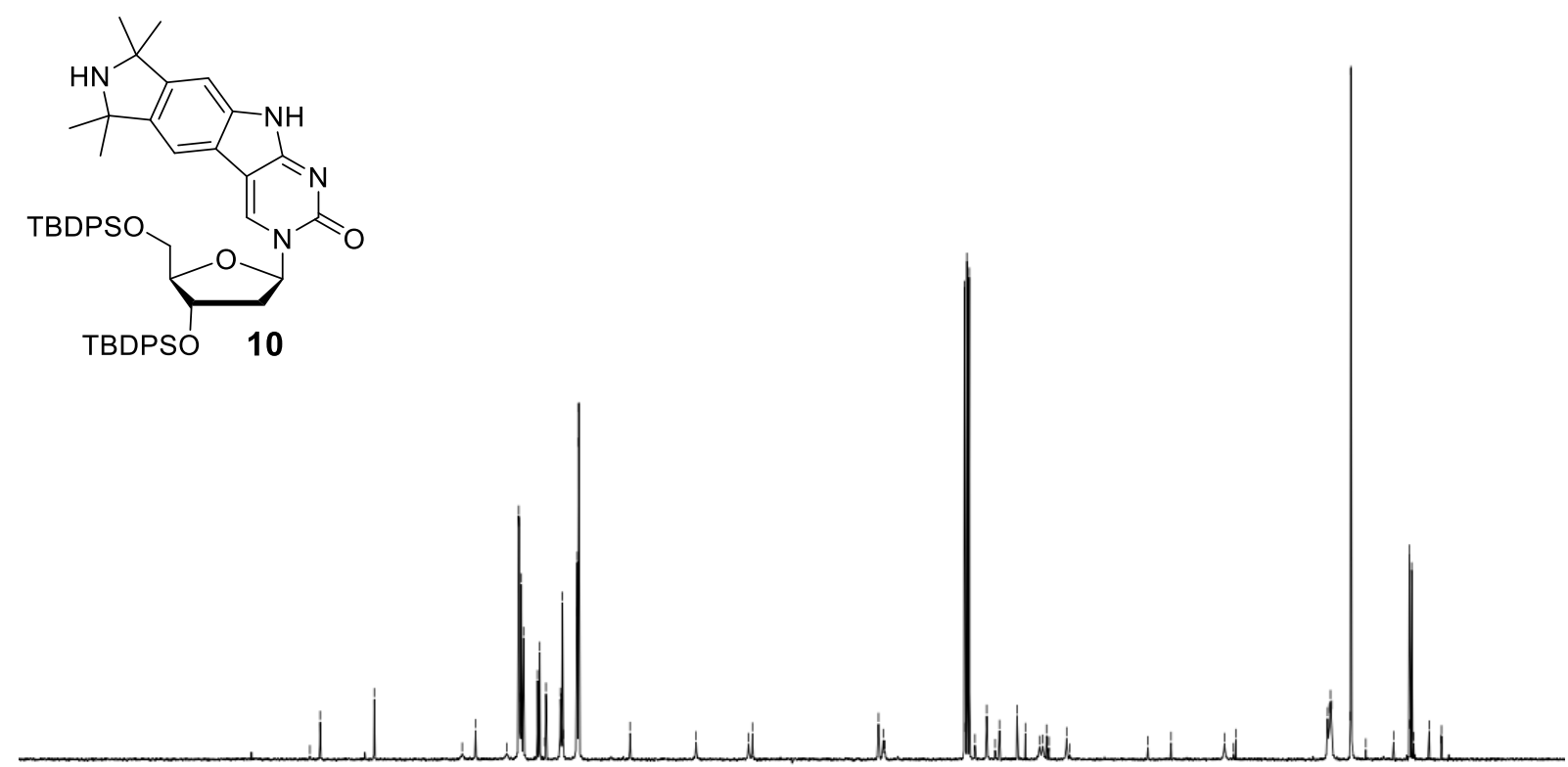

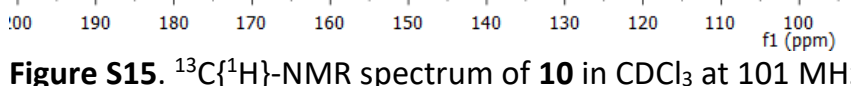




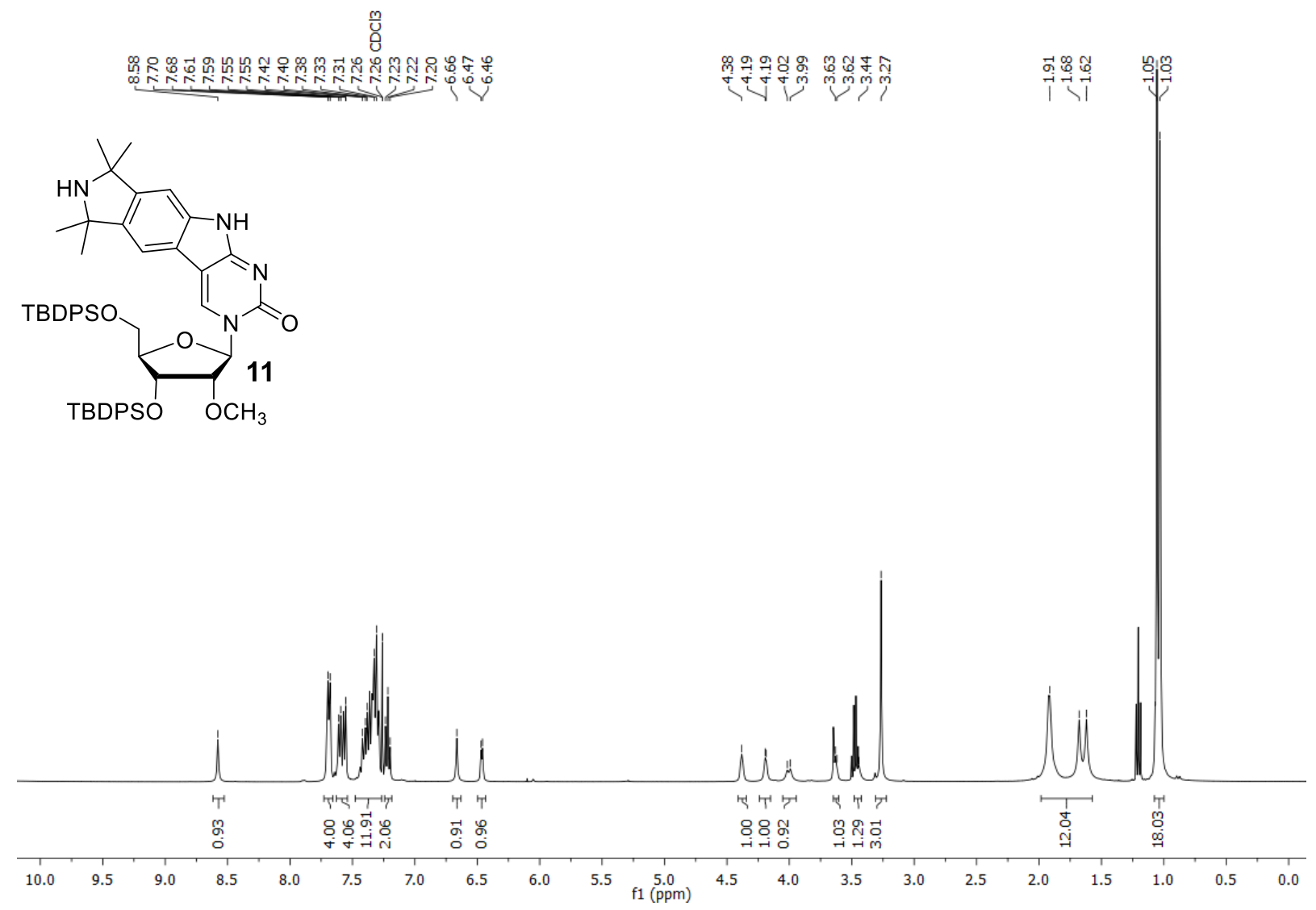

Figure S16. ${ }^{1} \mathrm{H}-\mathrm{NMR}$ spectrum of 11 in $\mathrm{CDCl}_{3}$ at $400 \mathrm{MHz}$.

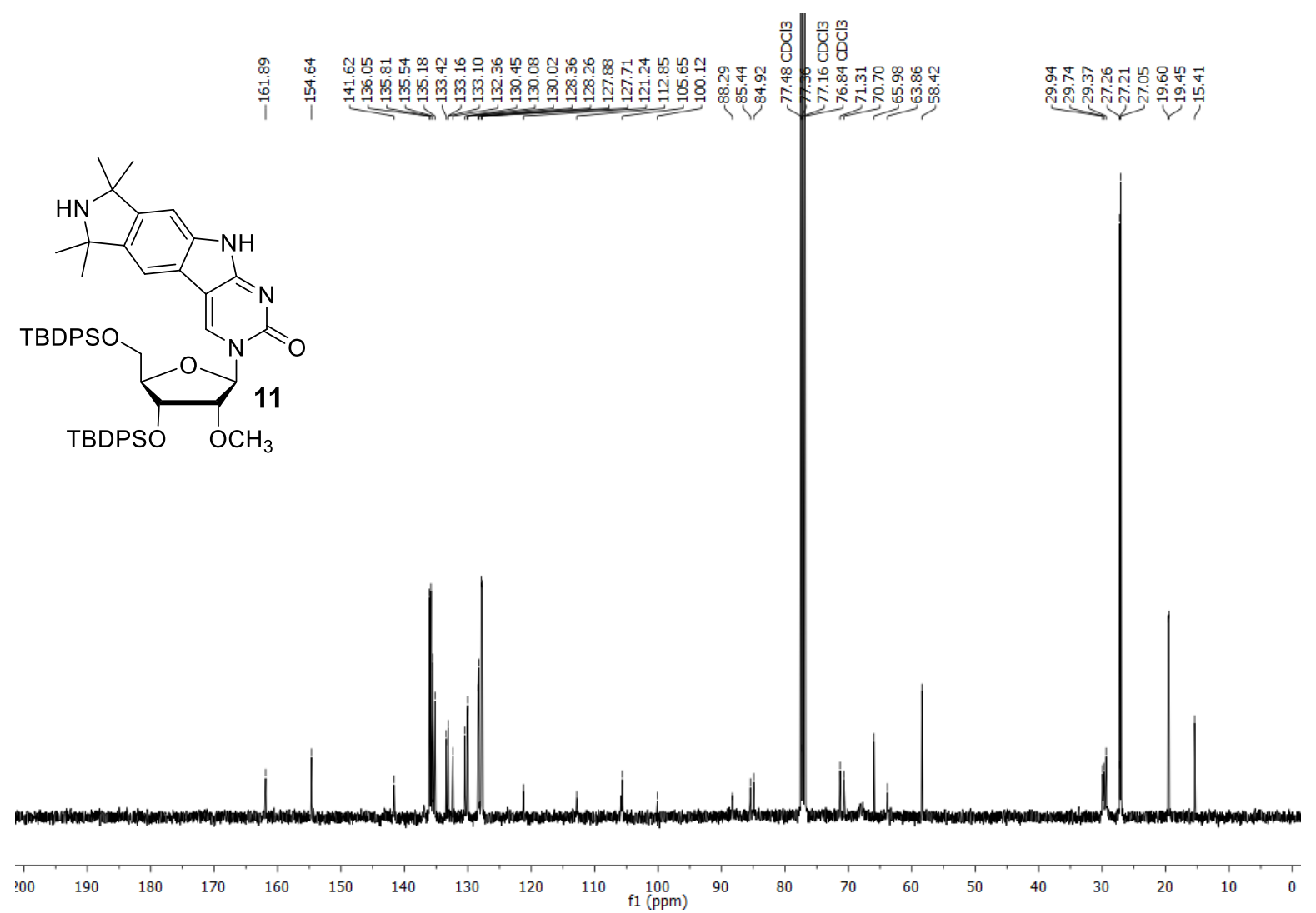

Figure S17. ${ }^{13} \mathrm{C}\left\{{ }^{1} \mathrm{H}\right\}-\mathrm{NMR}$ spectrum of 11 in $\mathrm{CDCl}_{3}$ at $101 \mathrm{MHz}$. 


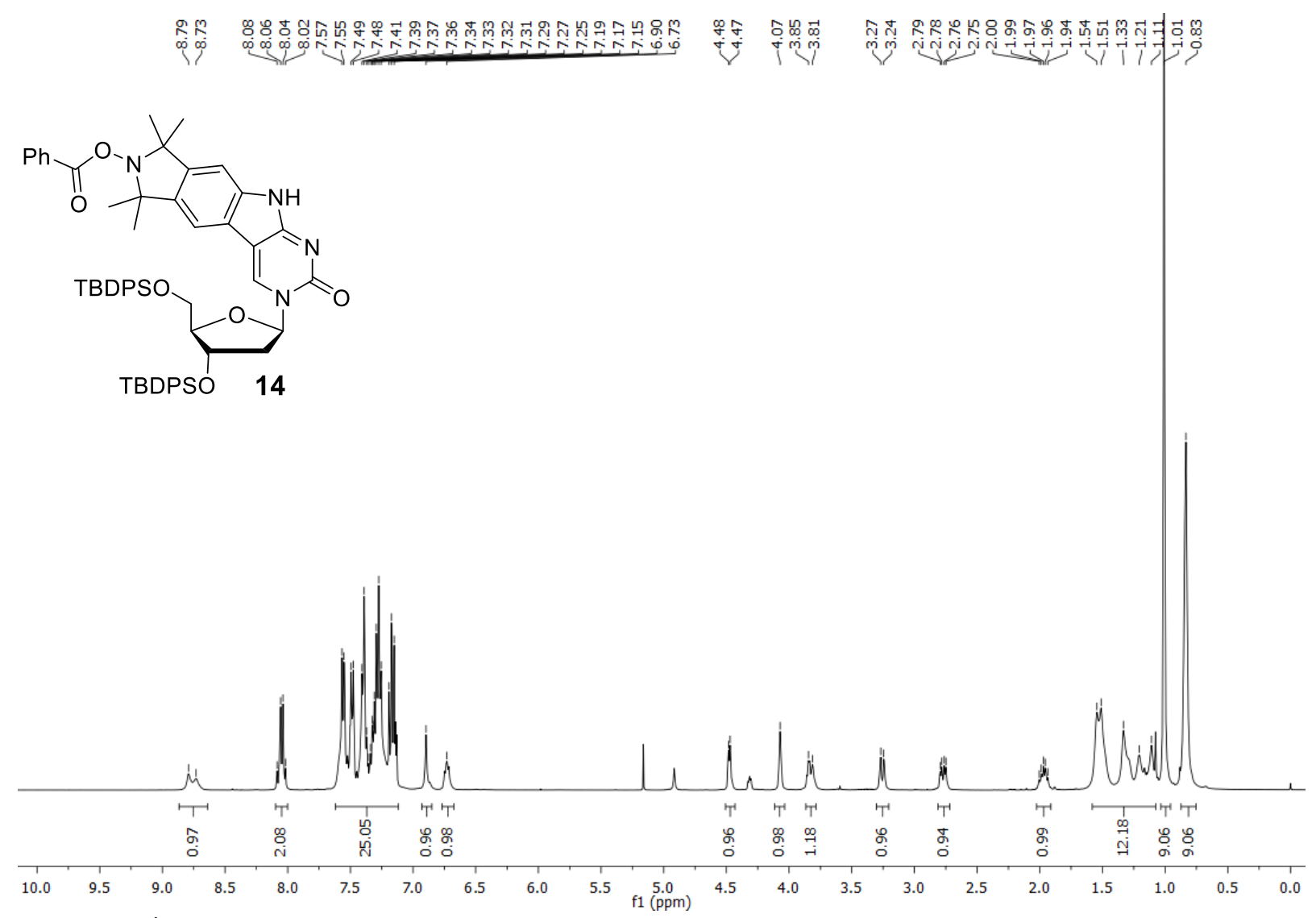

Figure S18. ${ }^{1} \mathrm{H}-\mathrm{NMR}$ spectrum of 14 in $\mathrm{CDCl}_{3}$ at $400 \mathrm{MHz}$.

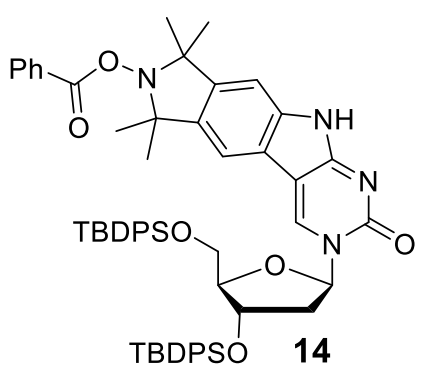

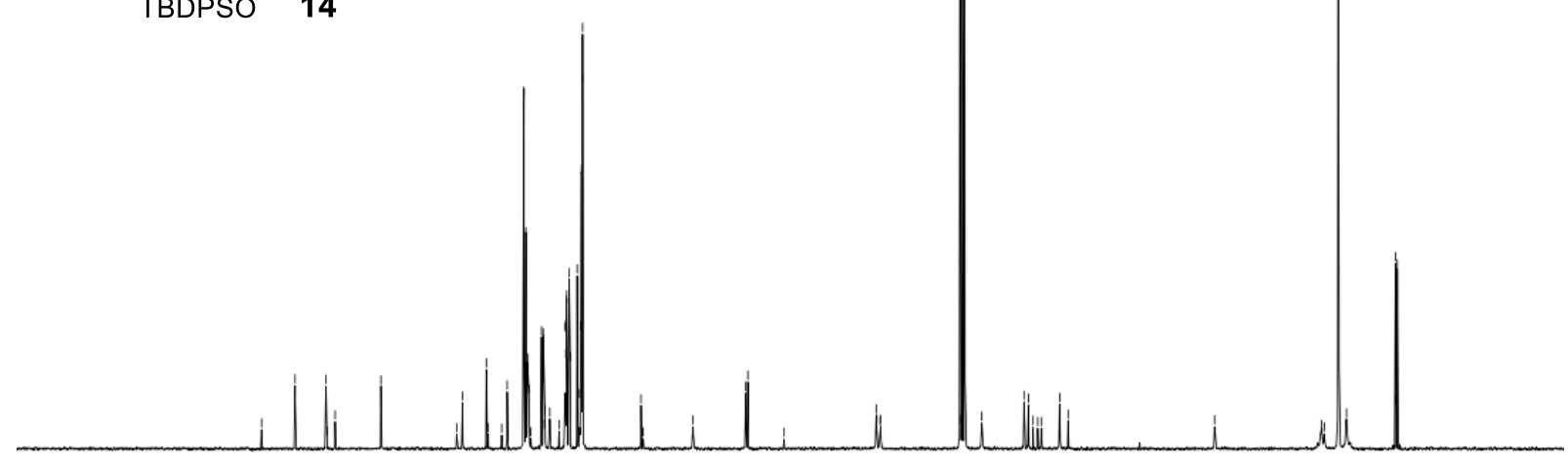

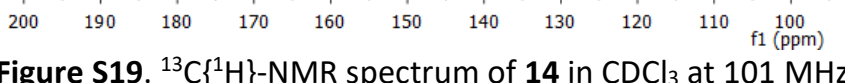




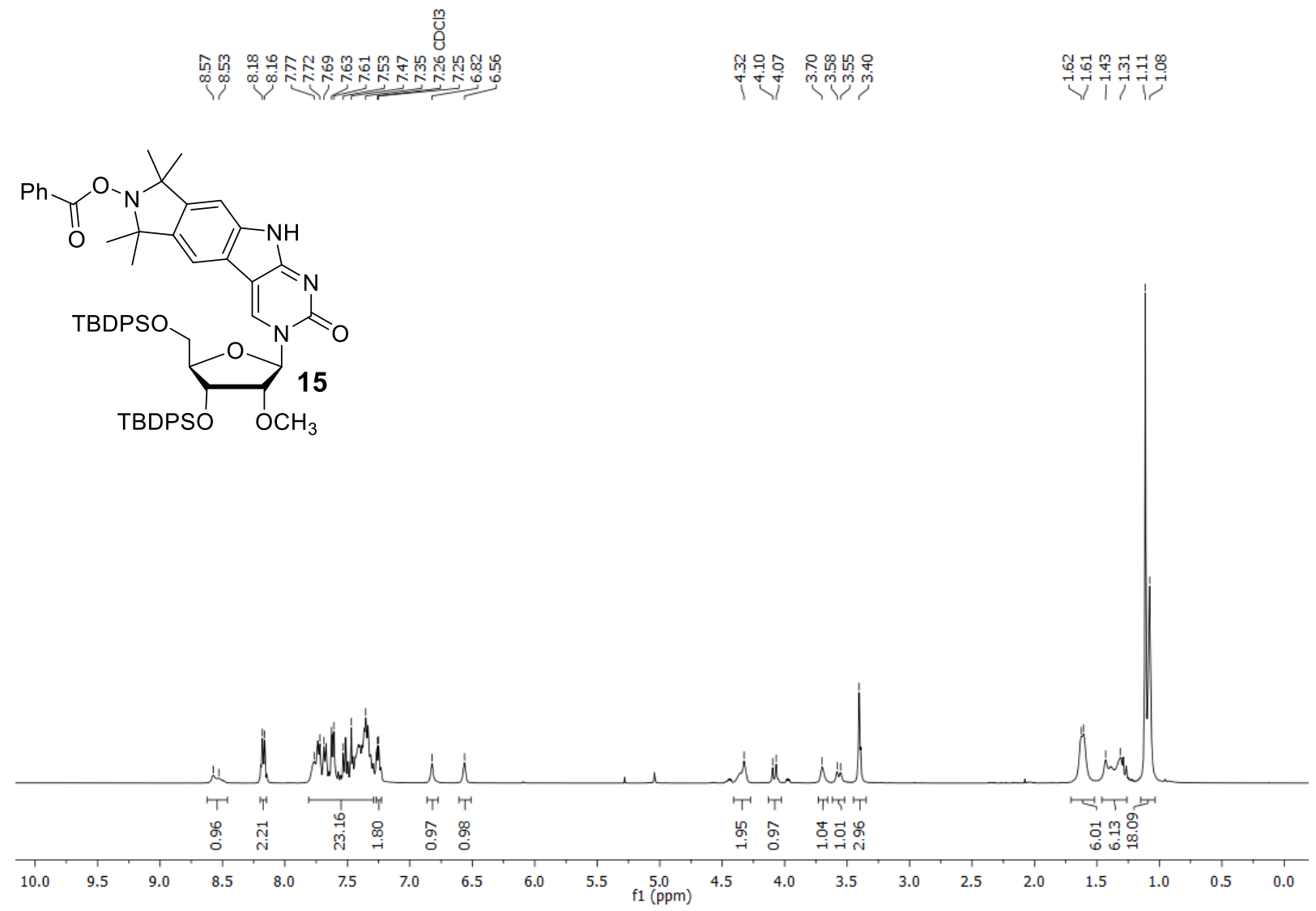

Figure S20. ${ }^{1} \mathrm{H}-\mathrm{NMR}$ spectrum of 15 in $\mathrm{CDCl}_{3}$ at $400 \mathrm{MHz}$.
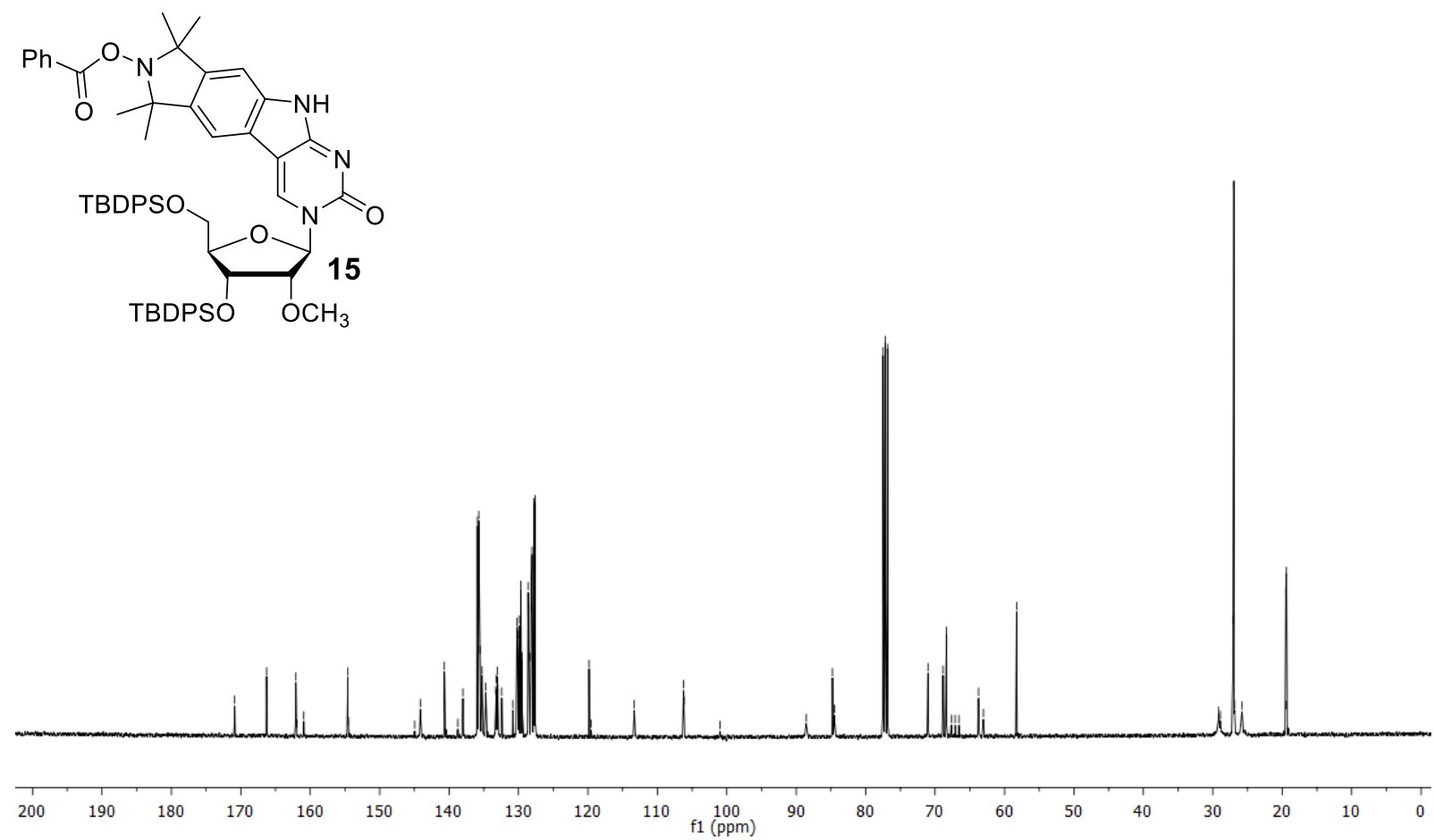

Figure S21. ${ }^{13} \mathrm{C}\left\{{ }^{1} \mathrm{H}\right\}-\mathrm{NMR}$ spectrum of 15 in $\mathrm{CDCl}_{3}$ at $101 \mathrm{MHz}$. 


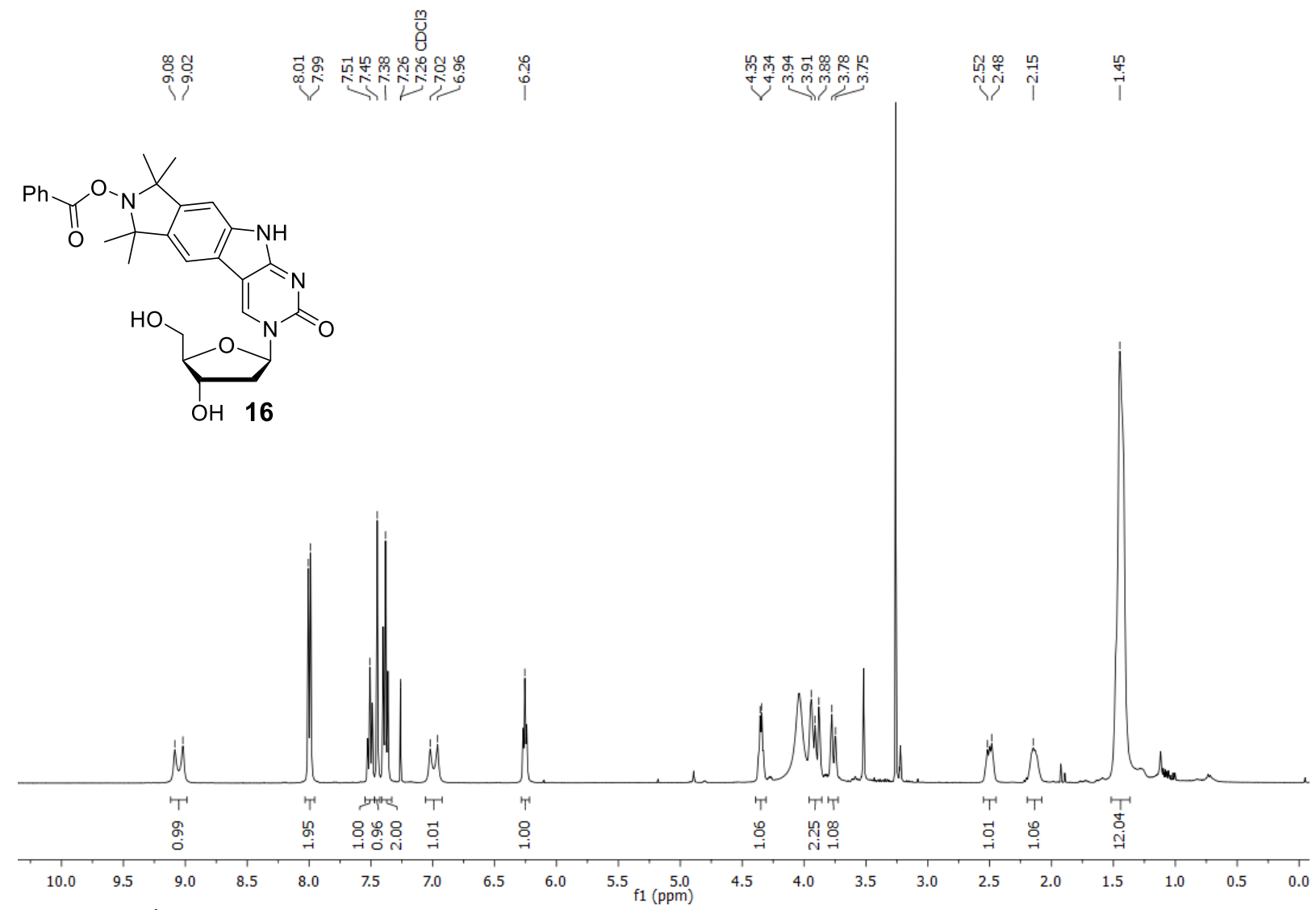

Figure S22. ${ }^{1} \mathrm{H}-\mathrm{NMR}$ spectrum of 16 in $\mathrm{CDCl}_{3}$ at $400 \mathrm{MHz}$.
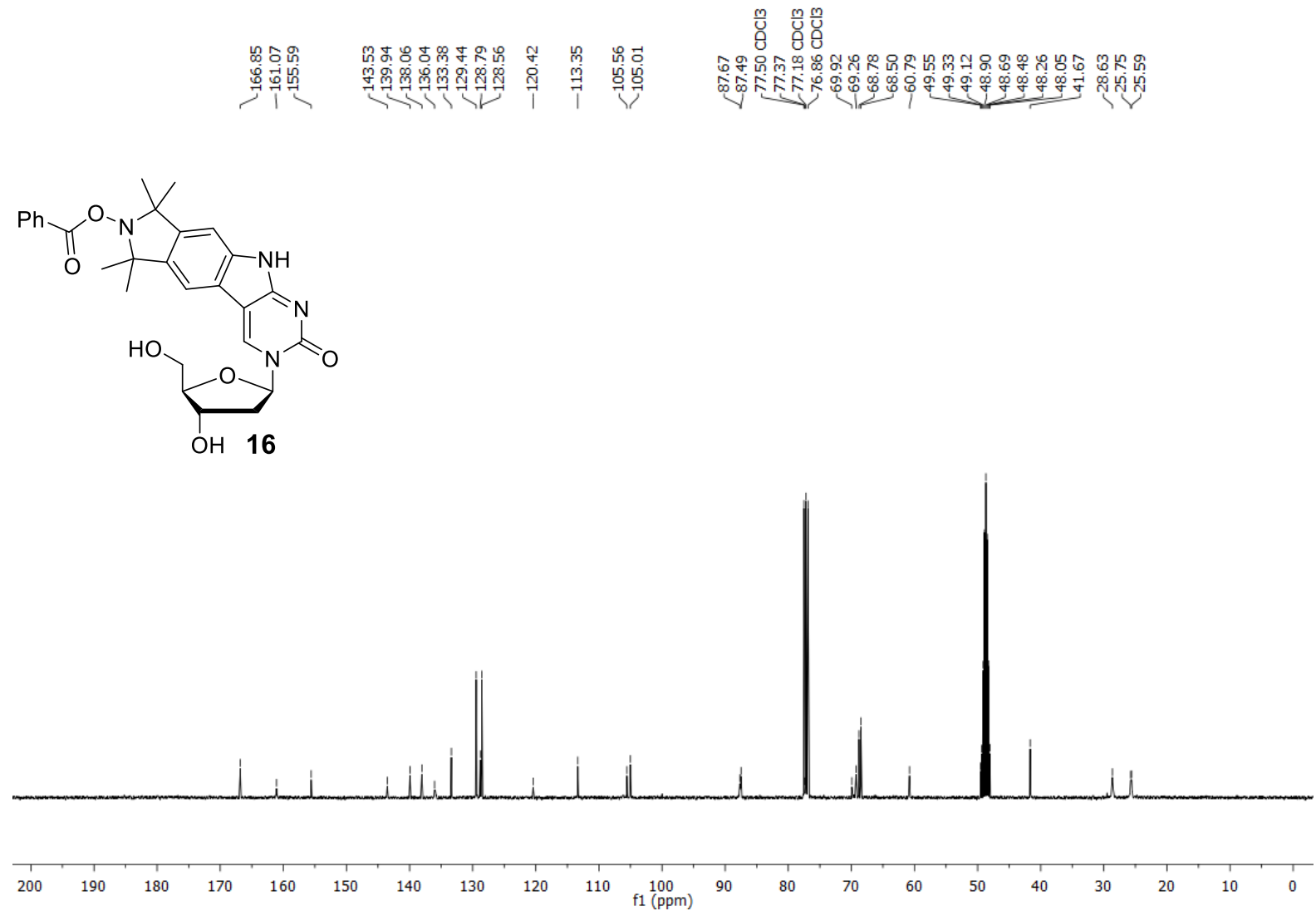

Figure S23. ${ }^{13} \mathrm{C}\left\{{ }^{1} \mathrm{H}\right\}-\mathrm{NMR}$ spectrum of 16 in $\mathrm{CDCl}_{3}$ at $101 \mathrm{MHz}$. 


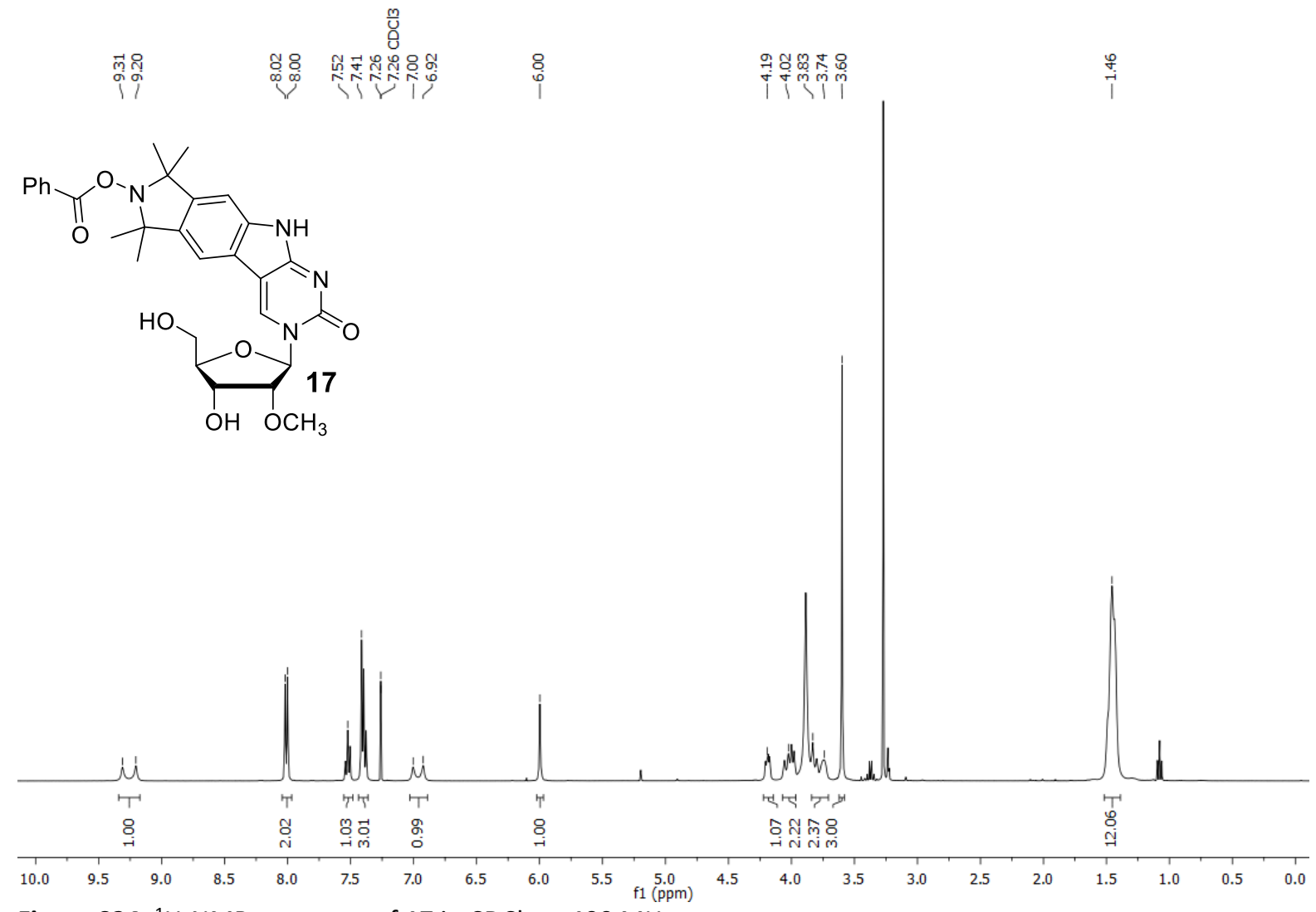

Figure S24. ${ }^{1} \mathrm{H}-\mathrm{NMR}$ spectrum of $17 \mathrm{in} \mathrm{CDCl}_{3}$ at $400 \mathrm{MHz}$.

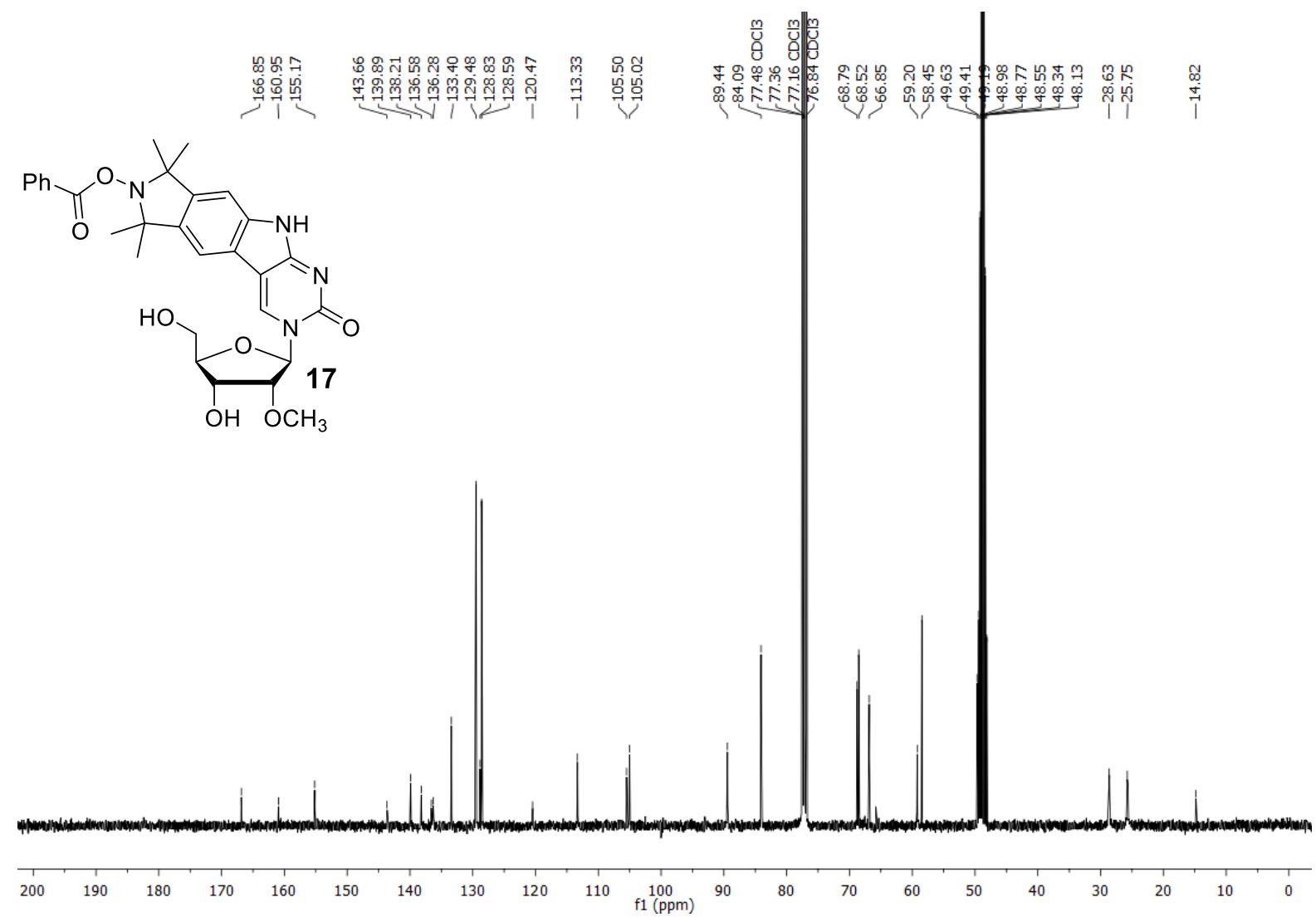

Figure S25. ${ }^{13} \mathrm{C}\left\{{ }^{1} \mathrm{H}\right\}-\mathrm{NMR}$ spectrum of $\mathbf{1 7}$ in $\mathrm{CDCl}_{3}$ at $101 \mathrm{MHz}$. 


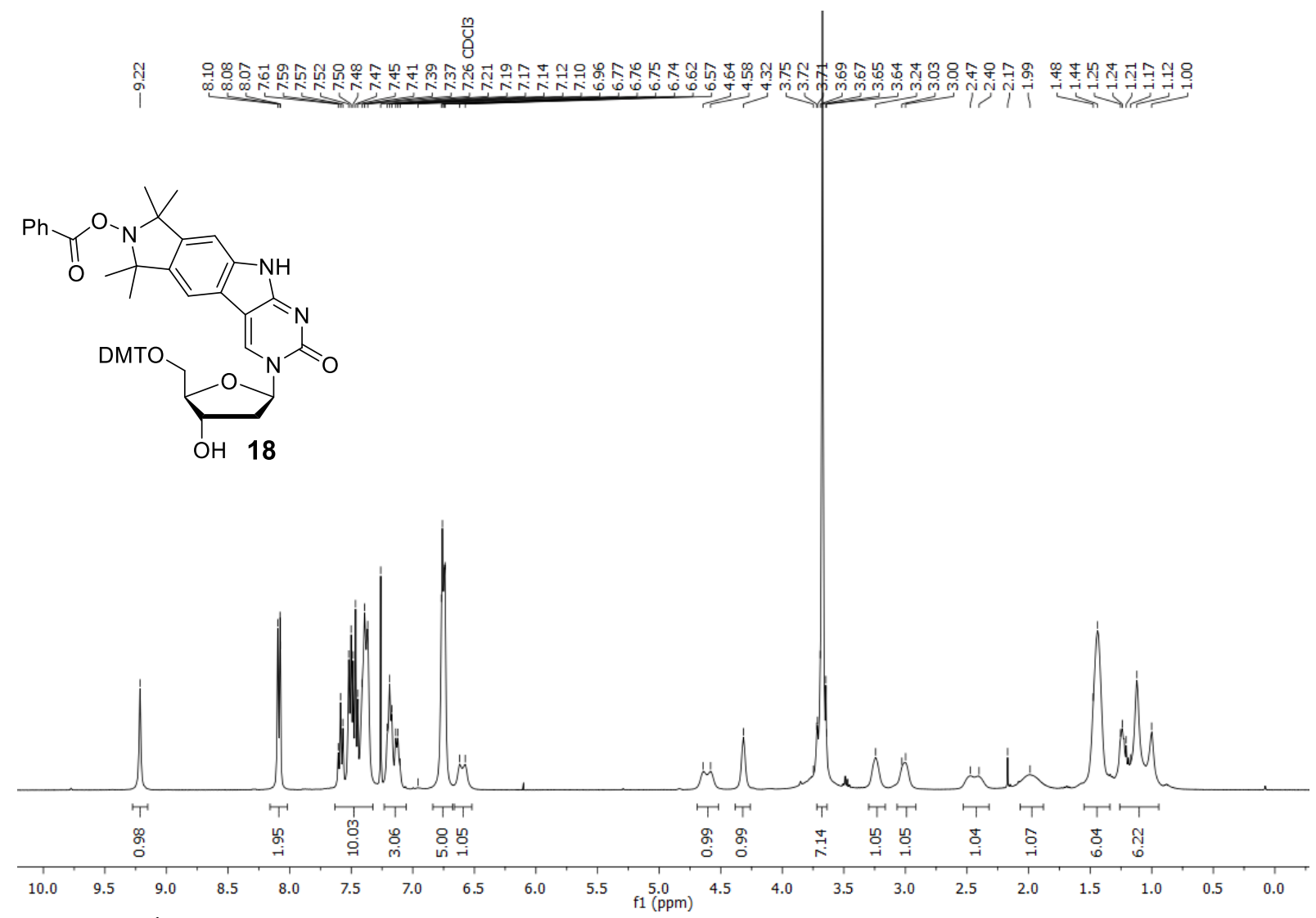

Figure S26. ${ }^{1} \mathrm{H}-\mathrm{NMR}$ spectrum of 18 in $\mathrm{CDCl}_{3}$ at $400 \mathrm{MHz}$.
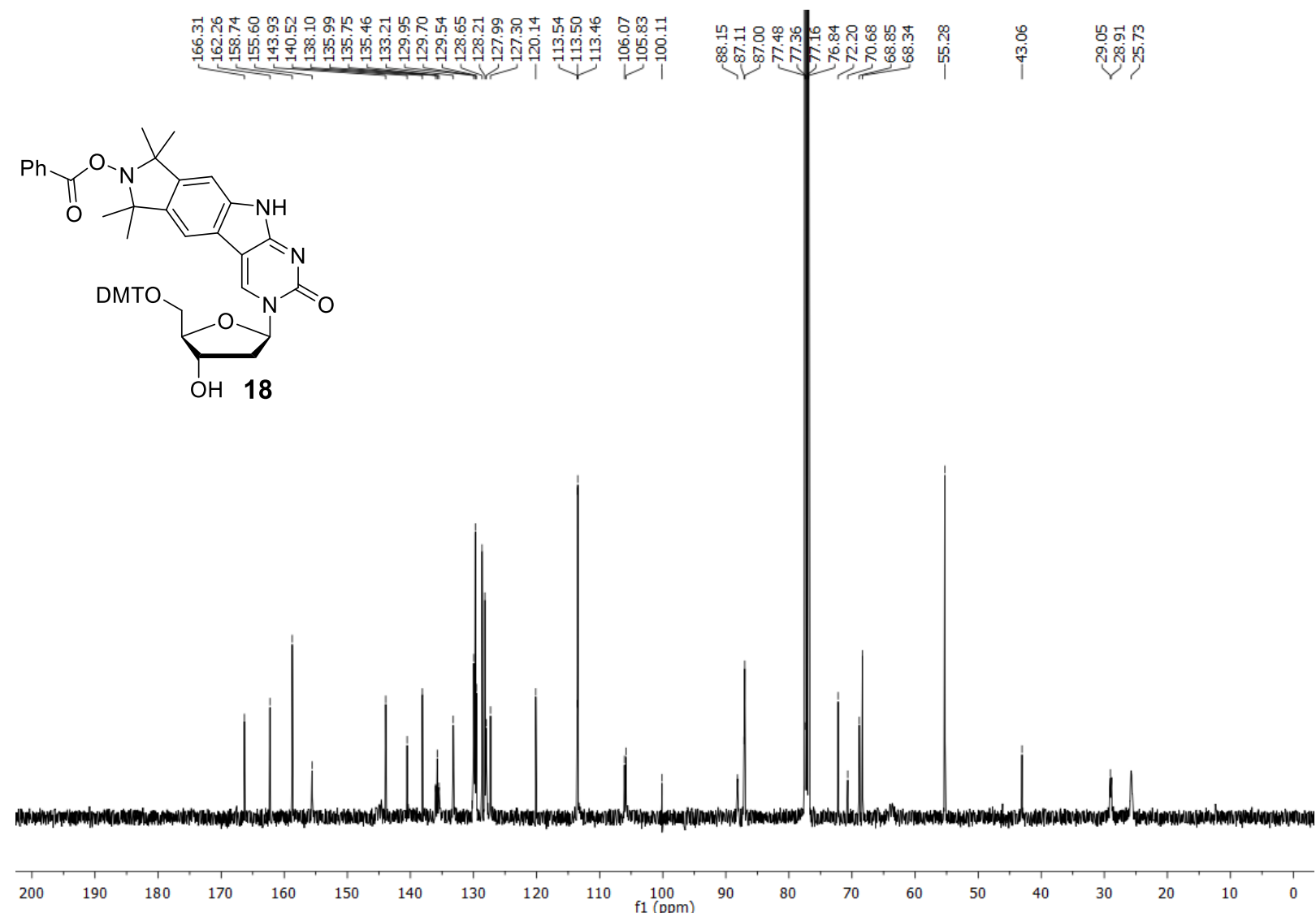

Figure S27. ${ }^{13} \mathrm{C}\left\{{ }^{1} \mathrm{H}\right\}-\mathrm{NMR}$ spectrum of 18 in $\mathrm{CDCl}_{3}$ at $101 \mathrm{MHz}$. 


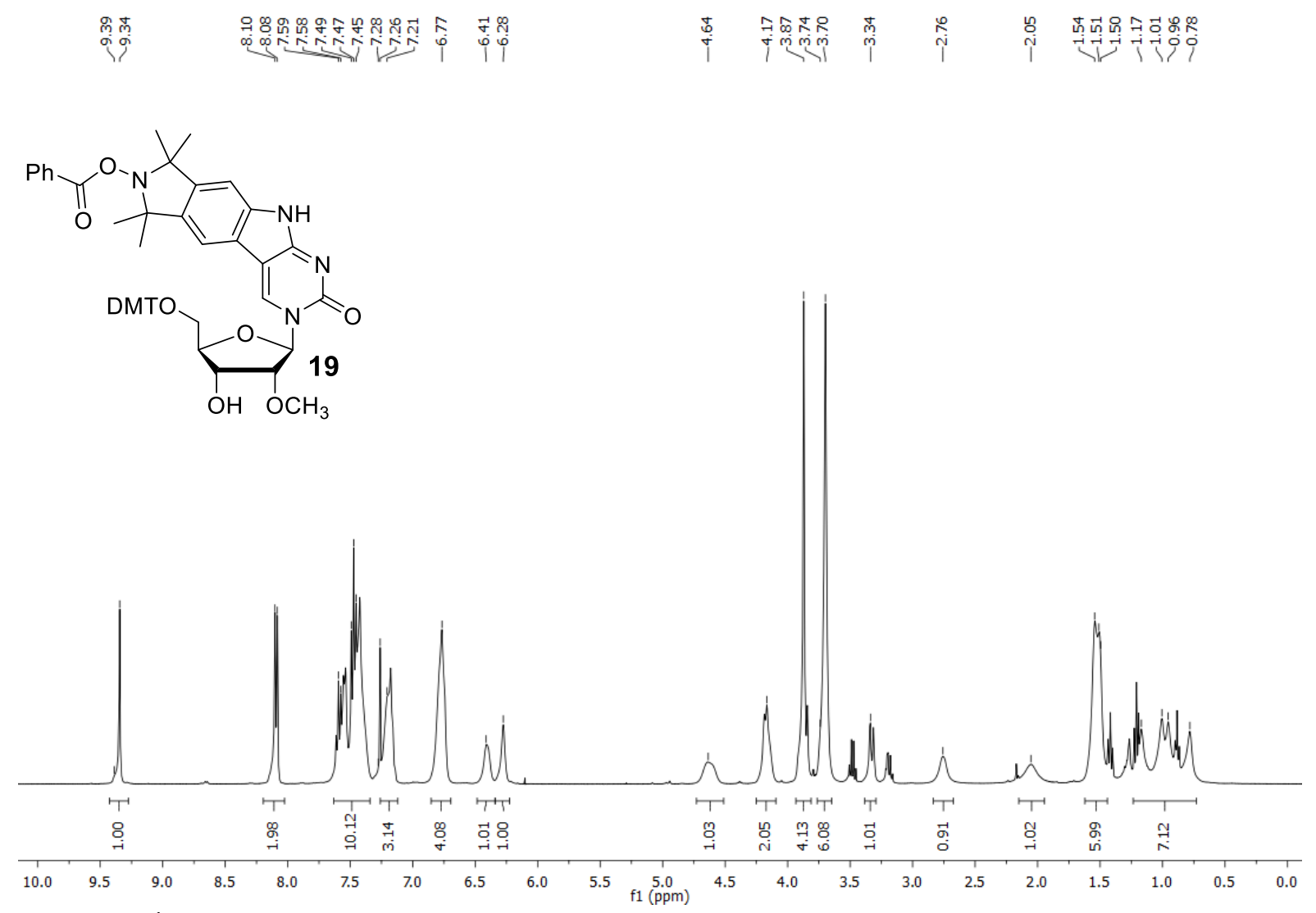

Figure S28. ${ }^{1} \mathrm{H}-\mathrm{NMR}$ spectrum of $19 \mathrm{in} \mathrm{CDCl}_{3}$ at $400 \mathrm{MHz}$.

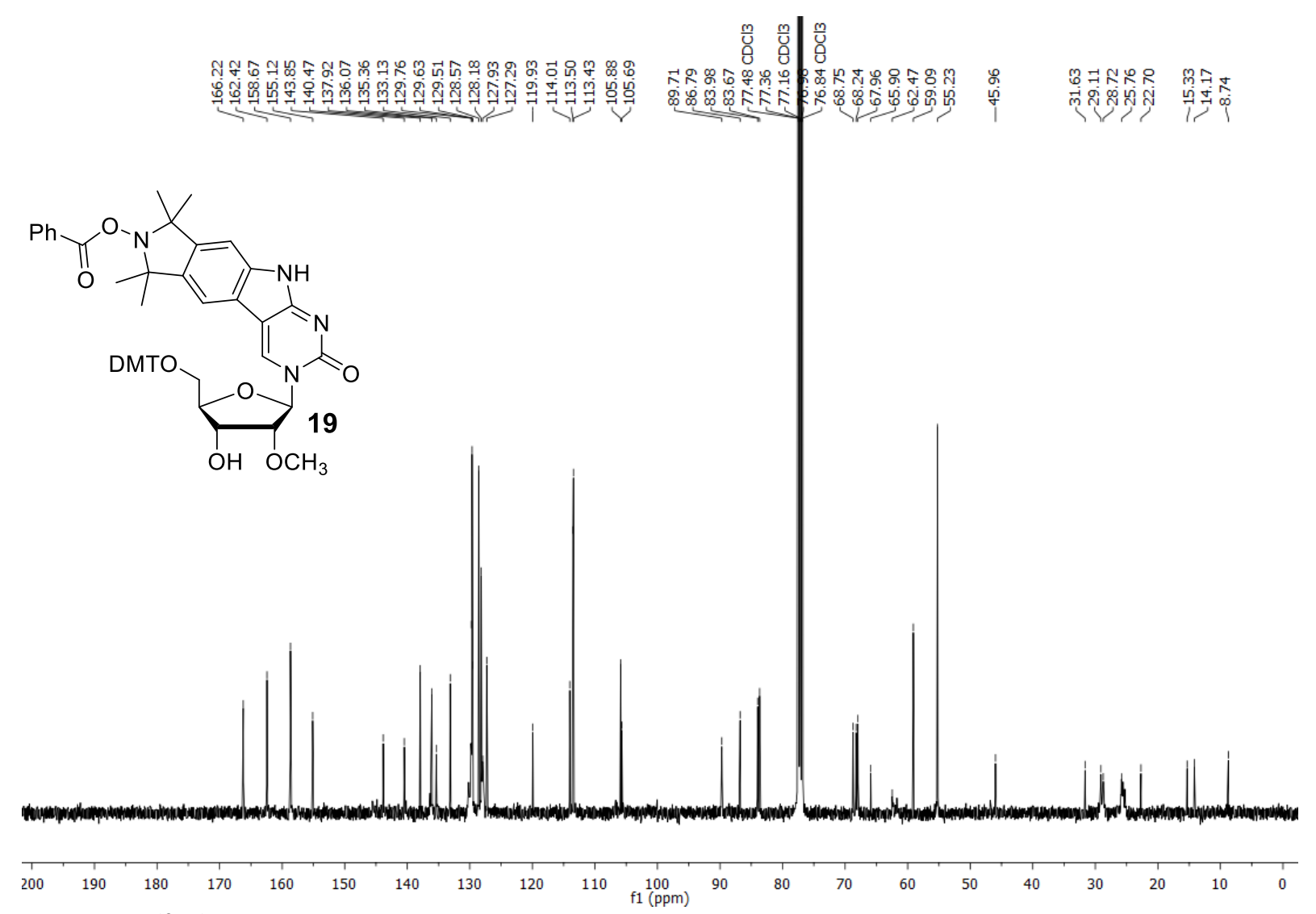

Figure S29. ${ }^{13} \mathrm{C}\left\{{ }^{1} \mathrm{H}\right\}-\mathrm{NMR}$ spectrum of 19 in $\mathrm{CDCl}_{3}$ at $101 \mathrm{MHz}$. 


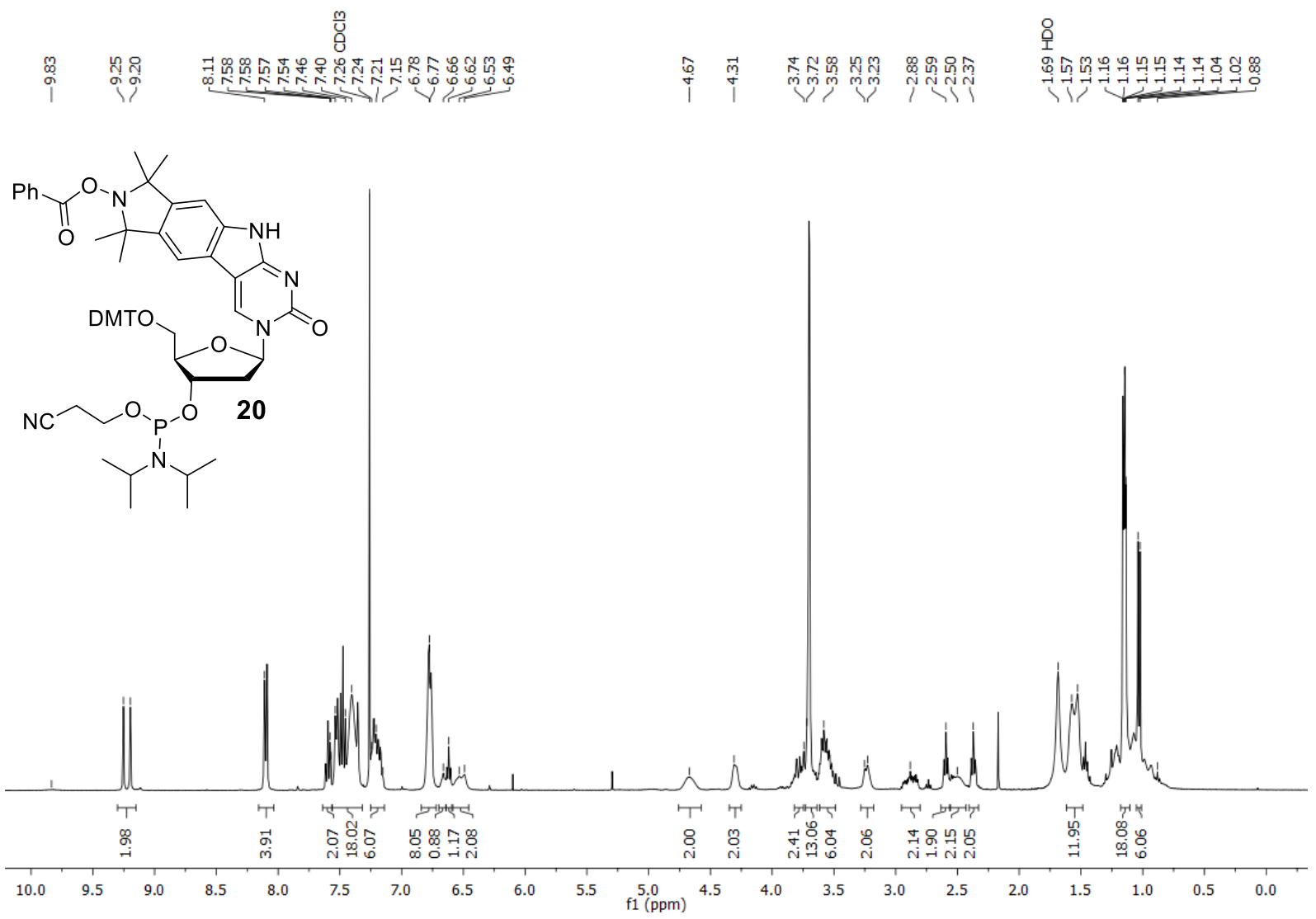

Figure S30. 1H-NMR spectrum of 20 in $\mathrm{CDCl} 3$ at $400 \mathrm{MHz}$.

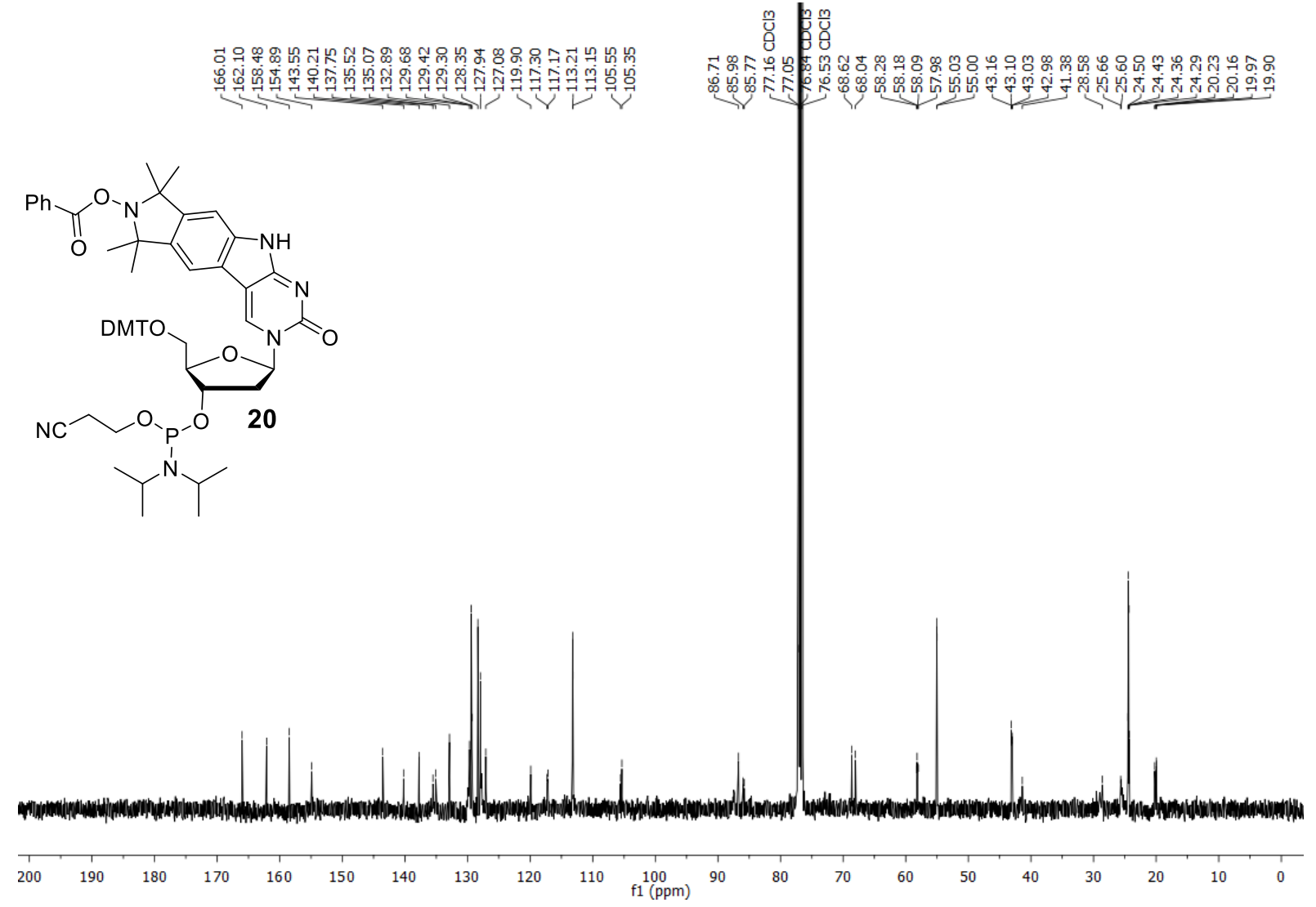

Figure S31. $13 \mathrm{C}\{1 \mathrm{H}\}-\mathrm{NMR}$ spectrum of 20 in $\mathrm{CDCl} 3$ at $101 \mathrm{MHz}$. 


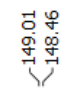

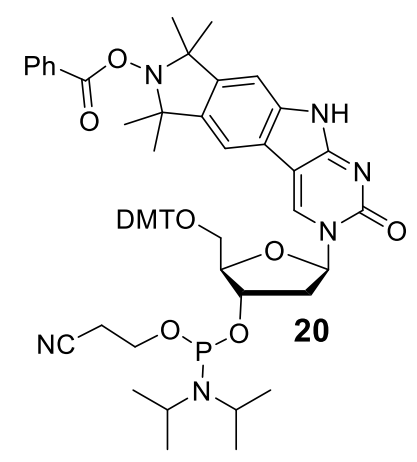

$\begin{array}{lllllllllll}200 & 190 & 180 & 170 & 160 & 150 & 140 & 130 & 120 & 110 & \begin{array}{l}100 \\ \mathrm{f} 1(\mathrm{ppm})\end{array}\end{array}$

Figure S32. ${ }^{31} \mathrm{P}-\mathrm{NMR}$ spectrum of 20 in $\mathrm{CDCl}_{3}$ at $162 \mathrm{MHz}$.

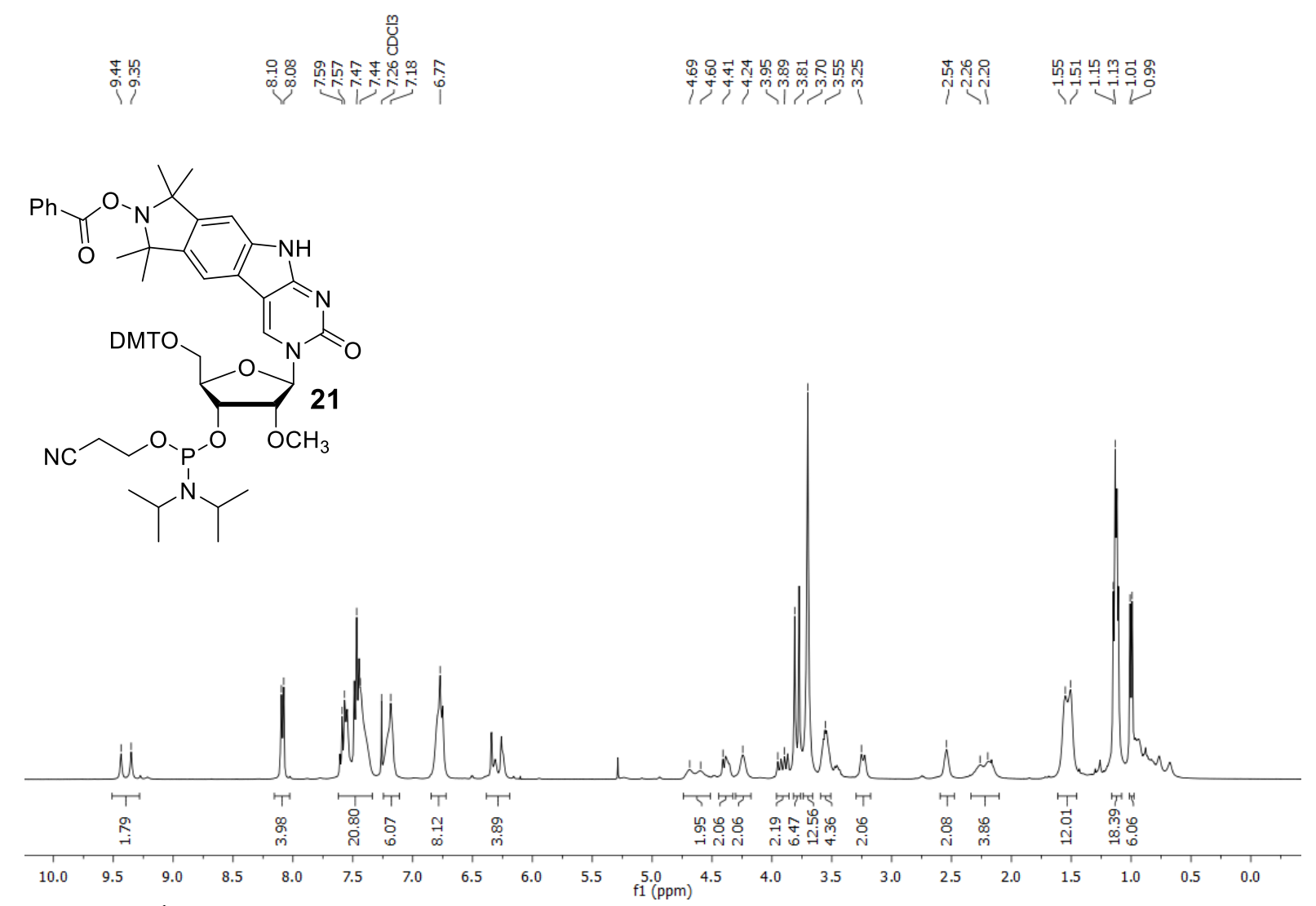

Figure S33. ${ }^{1} \mathrm{H}-\mathrm{NMR}$ spectrum of 21 in $\mathrm{CDCl}_{3}$ at $400 \mathrm{MHz}$. 


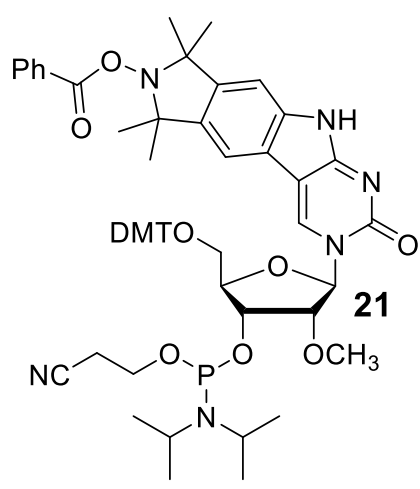

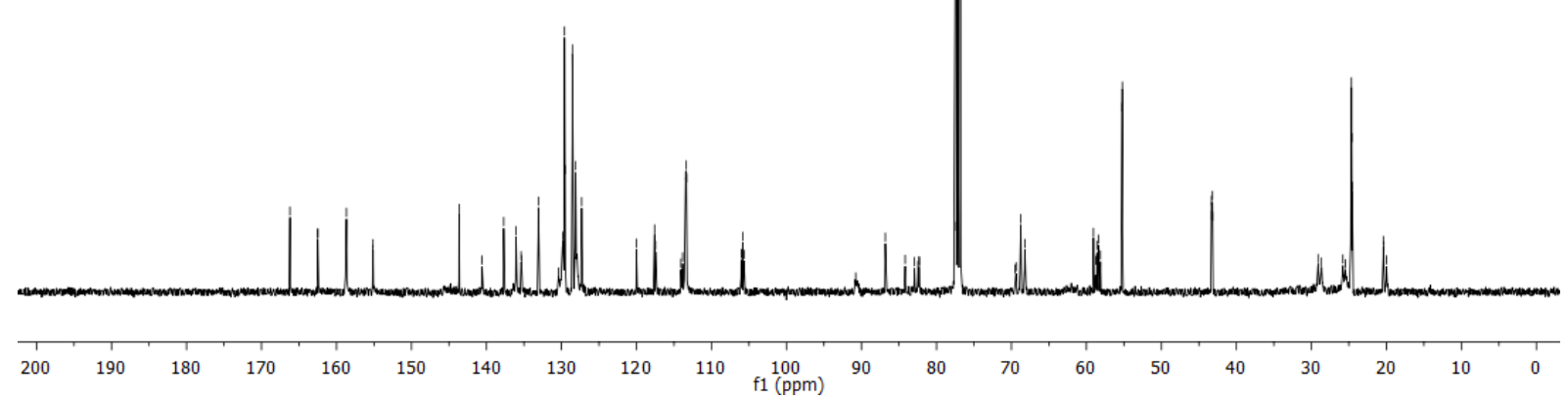

Figure S34. ${ }^{13} \mathrm{C}\left\{{ }^{1} \mathrm{H}\right\}-\mathrm{NMR}$ spectrum of 21 in $\mathrm{CDCl}_{3}$ at $101 \mathrm{MHz}$.

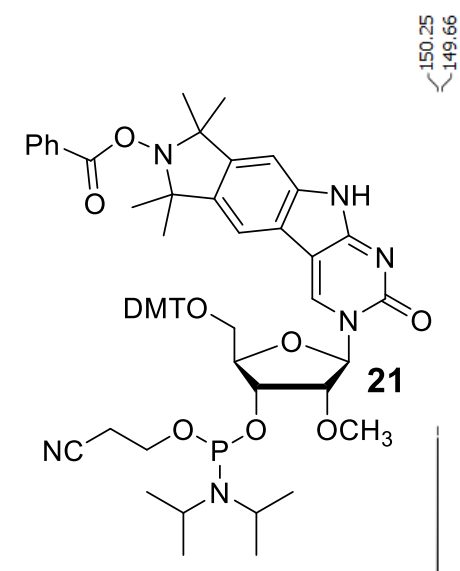

Figure S35. ${ }^{31} \mathrm{P}-\mathrm{NMR}$ spectrum of 21 in $\mathrm{CDCl}_{3}$ at $162 \mathrm{MHz}$. 


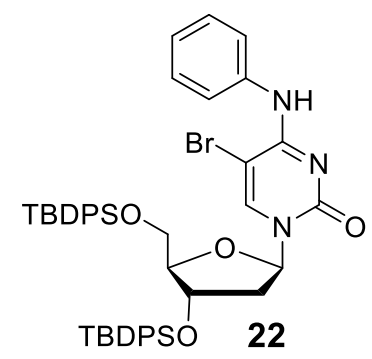

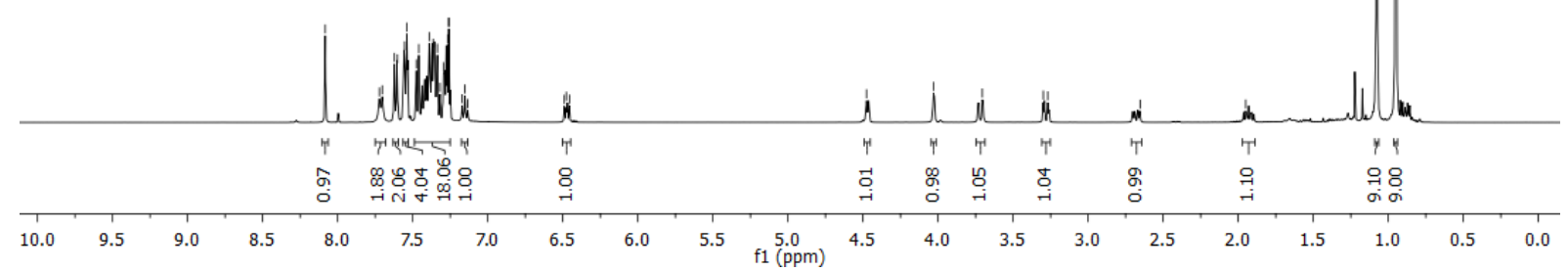

Figure S36. ${ }^{1} \mathrm{H}-\mathrm{NMR}$ spectrum of $22 \mathrm{in} \mathrm{CDCl}_{3}$ at $400 \mathrm{MHz}$.

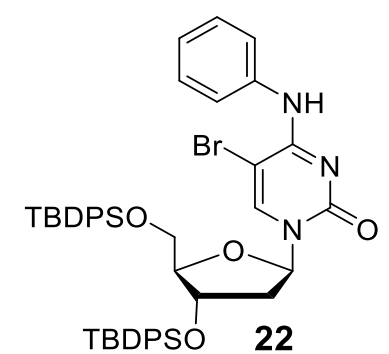

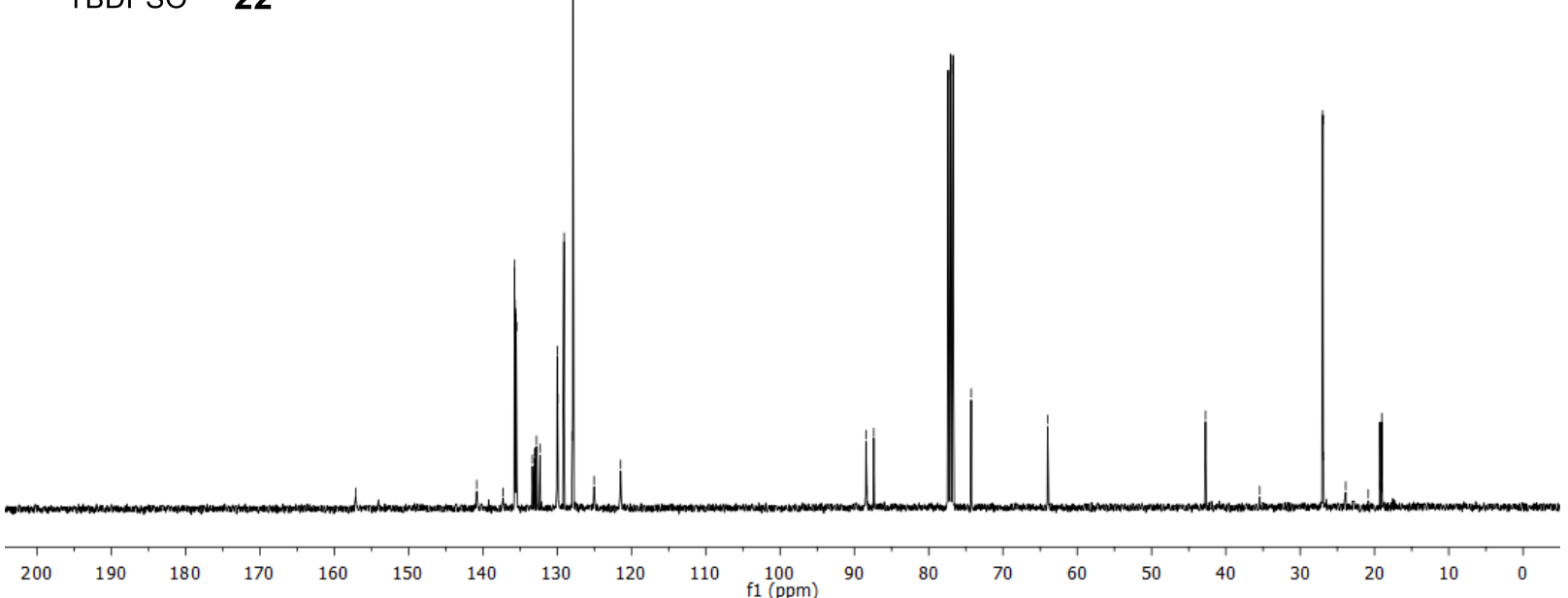

Figure S37. ${ }^{13} \mathrm{C}\left\{{ }^{1} \mathrm{H}\right\}-N M R$ spectrum of 22 in $\mathrm{CDCl}_{3}$ at $101 \mathrm{MHz}$. 


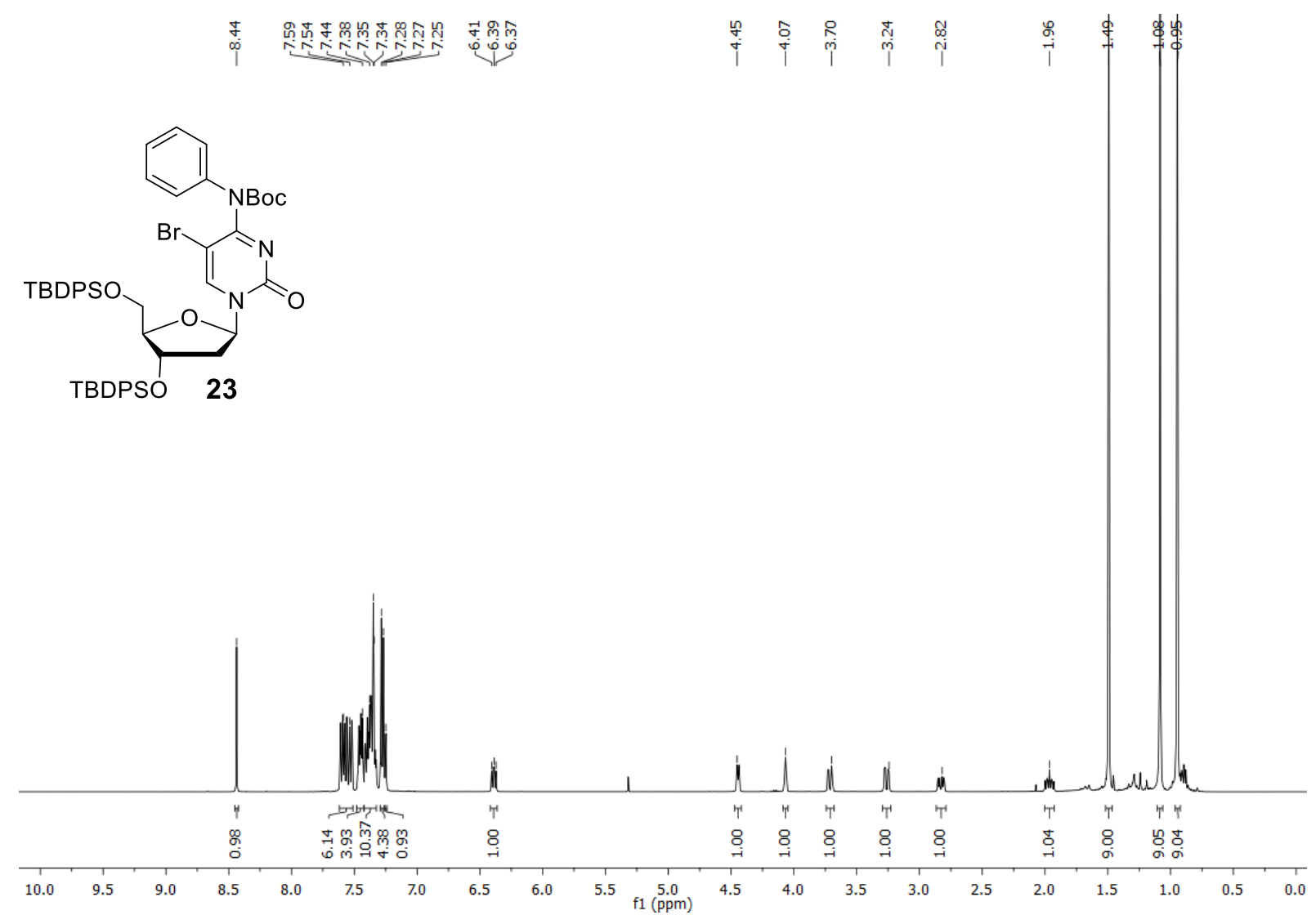

Figure S38. ${ }^{1} \mathrm{H}-\mathrm{NMR}$ spectrum of 23 in $\mathrm{CDCl}_{3}$ at $400 \mathrm{MHz}$.
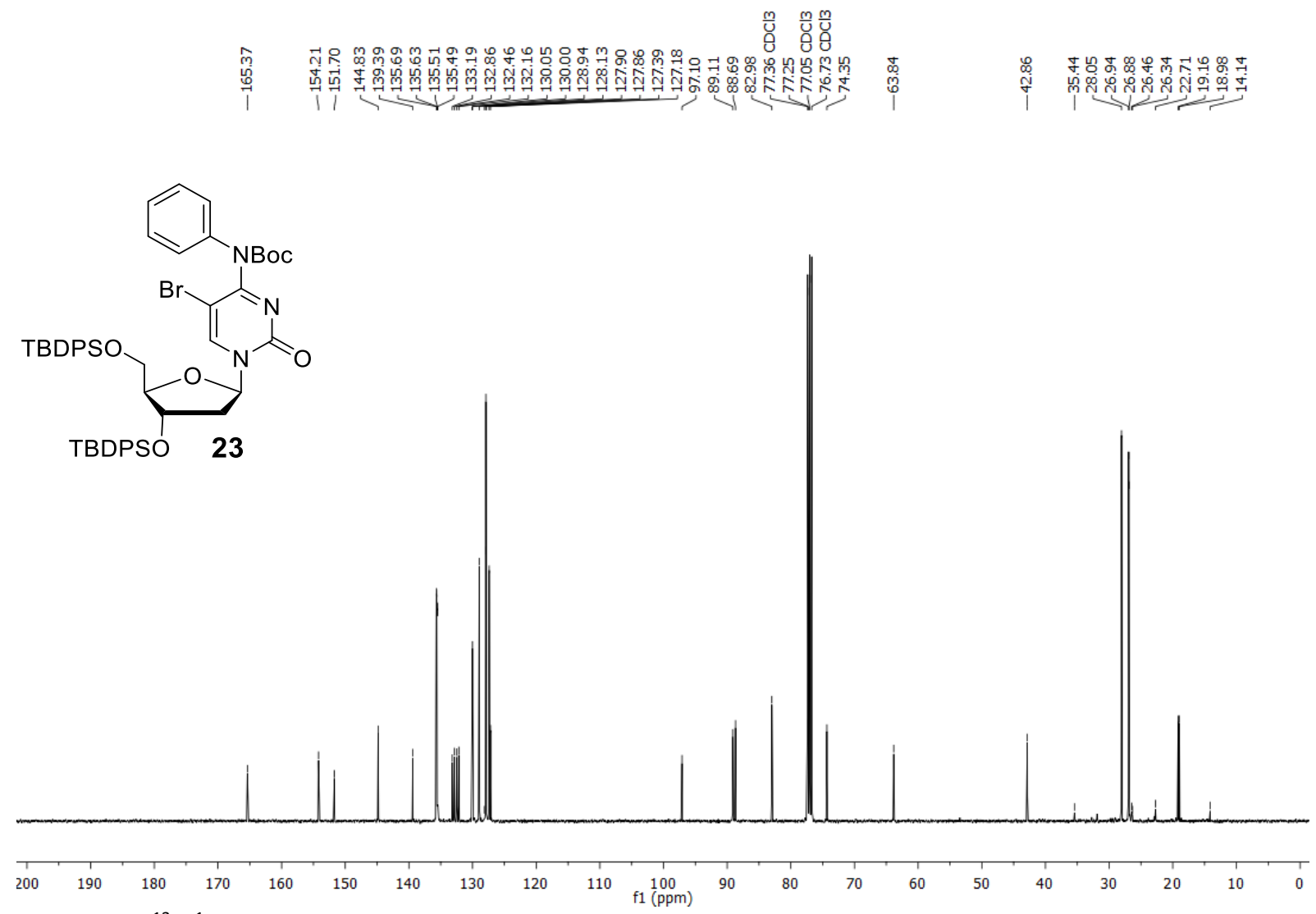

Figure S39. ${ }^{13} \mathrm{C}\left\{{ }^{1} \mathrm{H}\right\}-\mathrm{NMR}$ spectrum of 23 in $\mathrm{CDCl}_{3}$ at $101 \mathrm{MHz}$. 

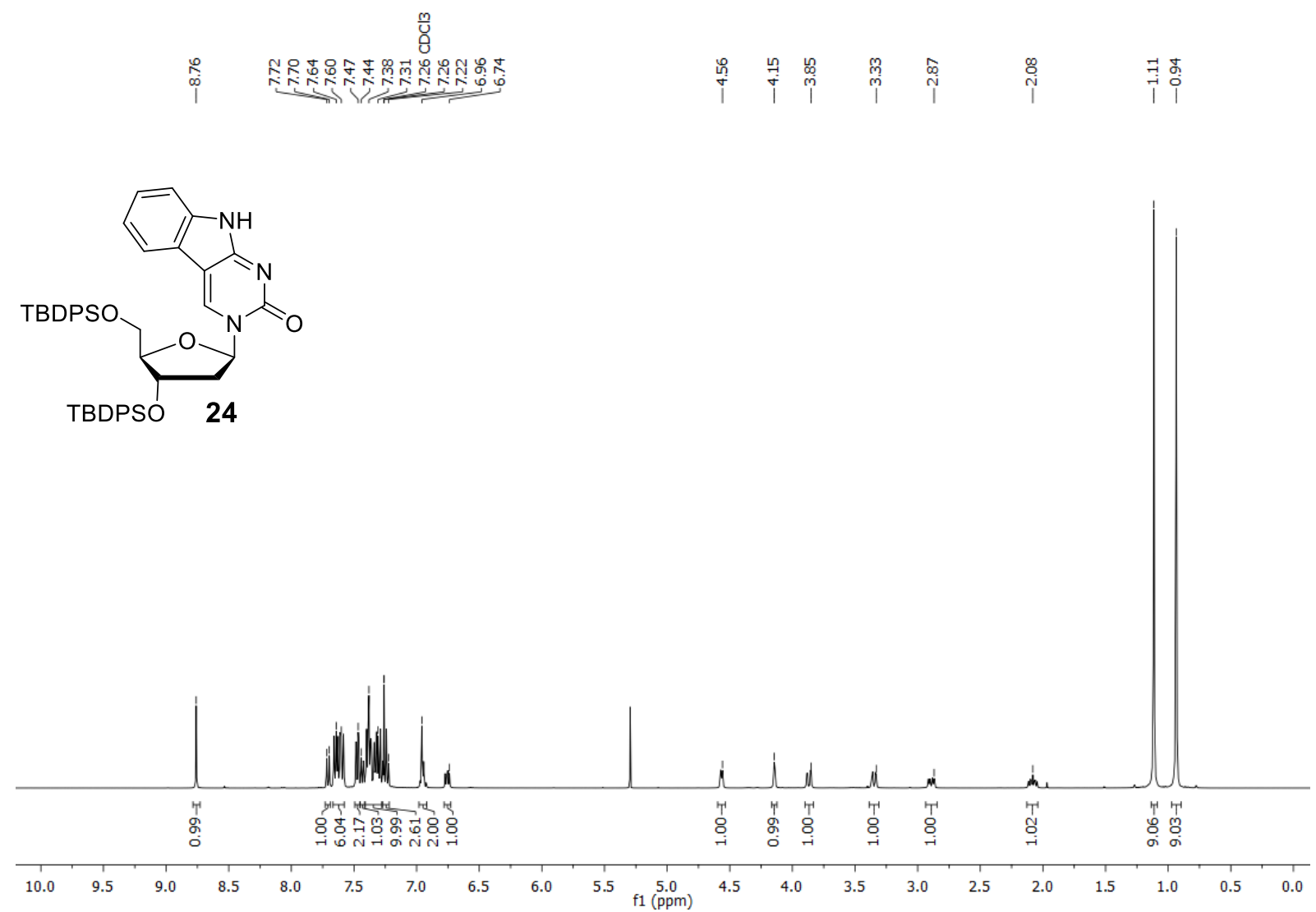

Figure S40. ${ }^{1} \mathrm{H}-\mathrm{NMR}$ spectrum of 24 in $\mathrm{CDCl}_{3}$ at $400 \mathrm{MHz}$.

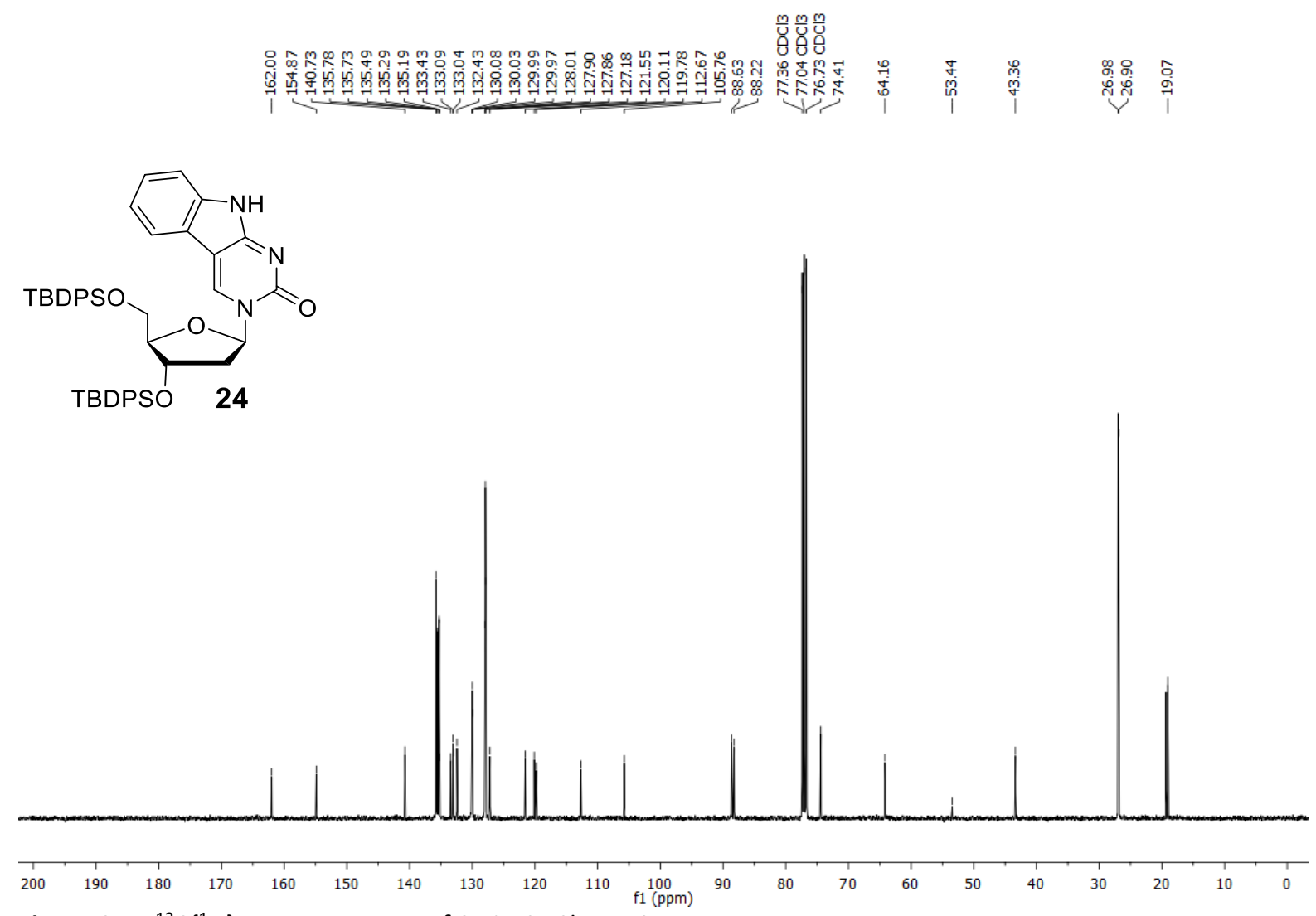

Figure S41. ${ }^{13} \mathrm{C}\left\{{ }^{1} \mathrm{H}\right\}-\mathrm{NMR}$ spectrum of 24 in $\mathrm{CDCl}_{3}$ at $101 \mathrm{MHz}$. 


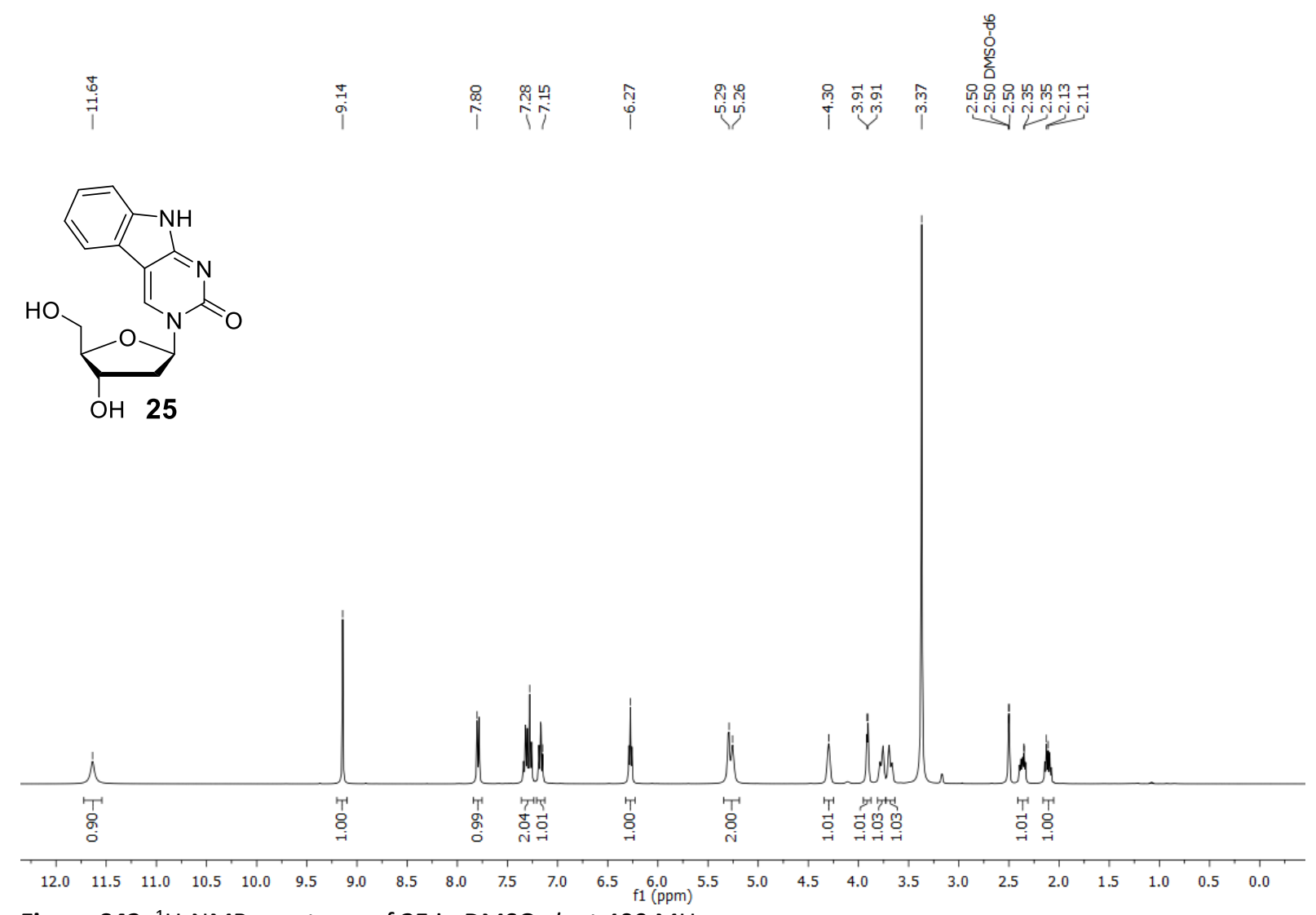

Figure S42. ${ }^{1} \mathrm{H}-\mathrm{NMR}$ spectrum of 25 in DMSO- $d_{6}$ at $400 \mathrm{MHz}$.
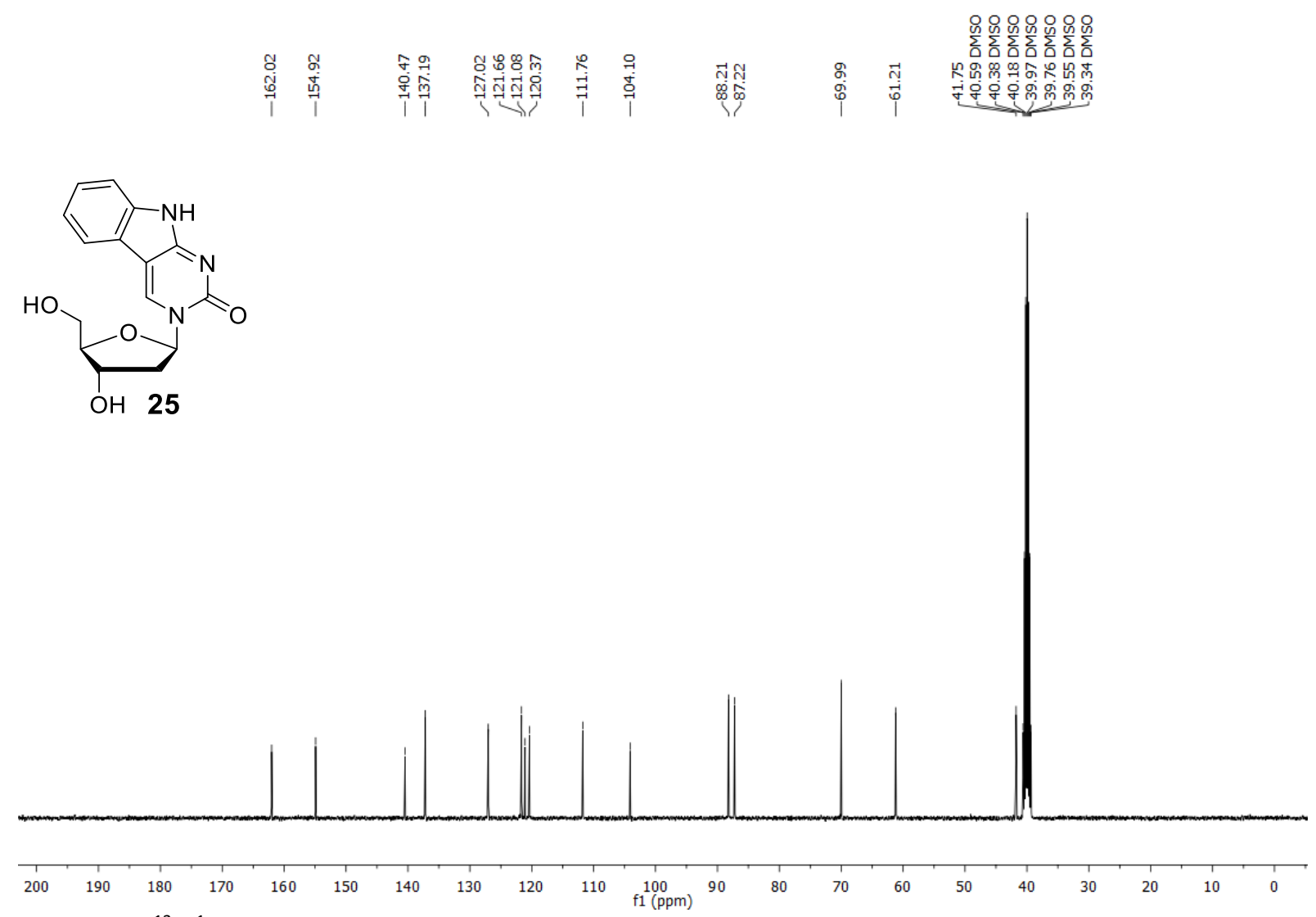

Figure S43. ${ }^{13} \mathrm{C}\left\{{ }^{1} \mathrm{H}\right\}-\mathrm{NMR}$ spectrum of 25 in DMSO-d $d_{6}$ at $101 \mathrm{MHz}$. 
<smiles>COCC1OC2COC1C(n1cc3c(nc1=O)[nH]c1ccccc13)O2</smiles>

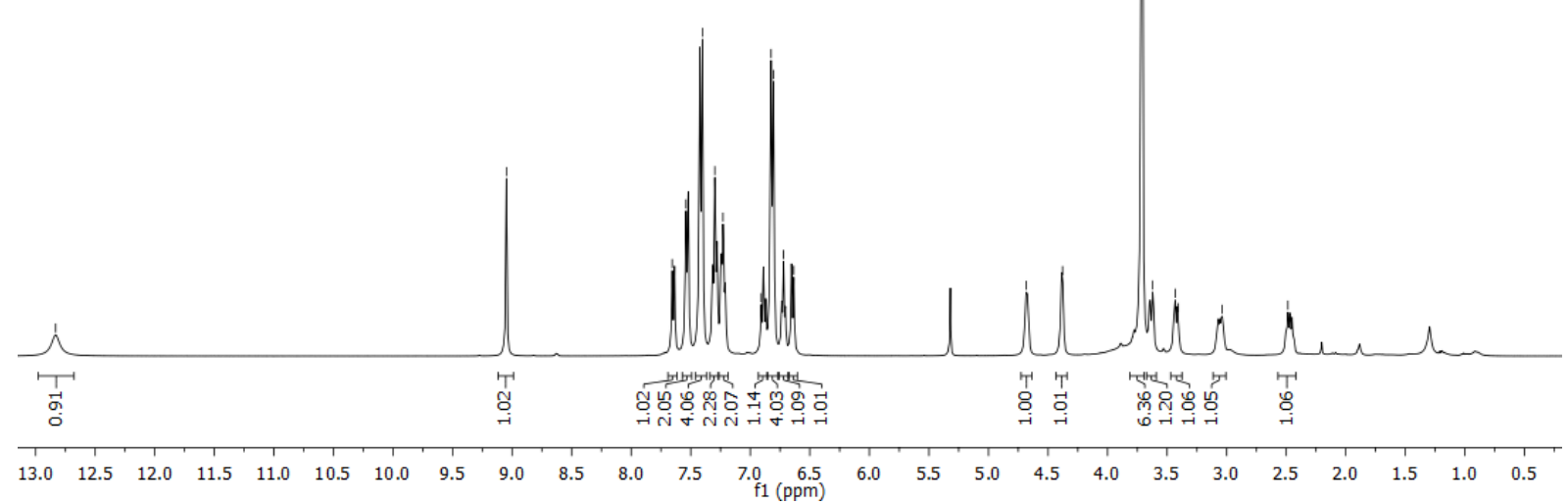

Figure S44. ${ }^{1} \mathrm{H}-\mathrm{NMR}$ spectrum of 26 in $\mathrm{CDCl}_{3}$ at $400 \mathrm{MHz}$.

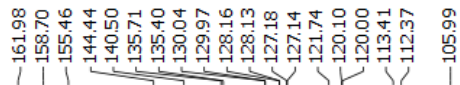

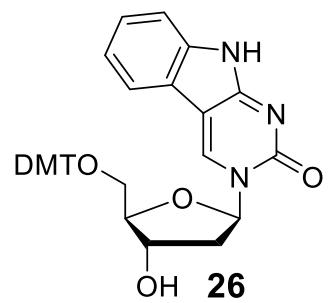

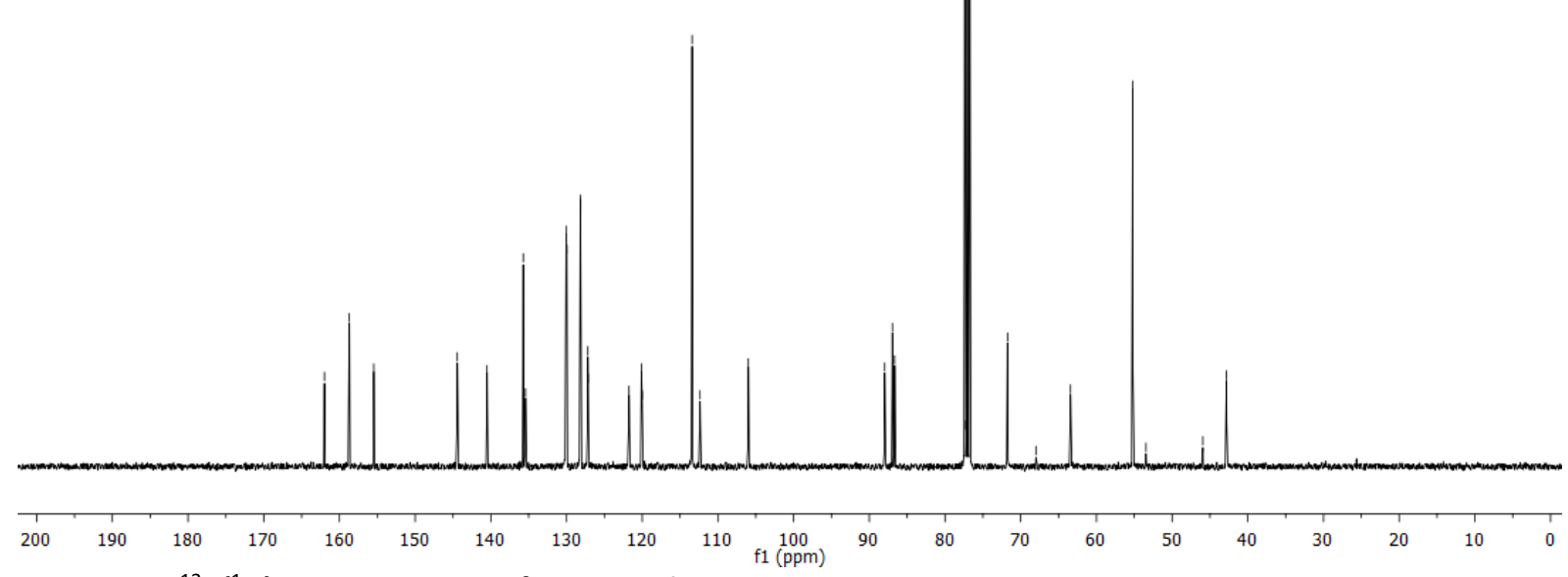

Figure S45. ${ }^{13} \mathrm{C}\left\{{ }^{1} \mathrm{H}\right\}-\mathrm{NMR}$ spectrum of 26 in $\mathrm{CDCl}_{3}$ at $101 \mathrm{MHz}$. 


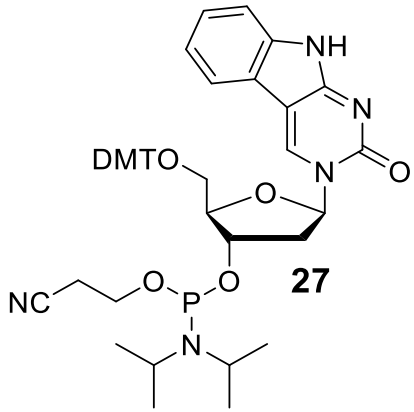

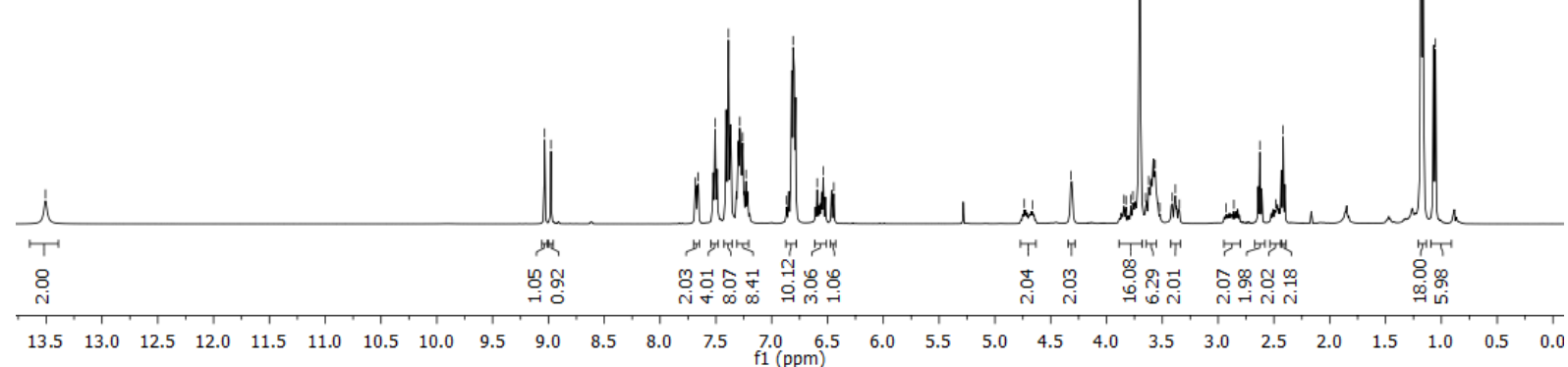

Figure S46. ${ }^{1} \mathrm{H}-\mathrm{NMR}$ spectrum of 27 in $\mathrm{CDCl}_{3}$ at $400 \mathrm{MHz}$.

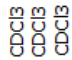

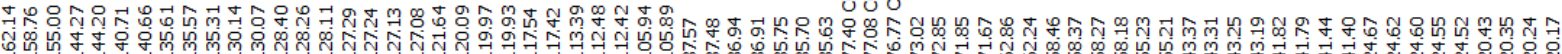

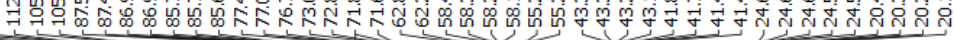<smiles></smiles>

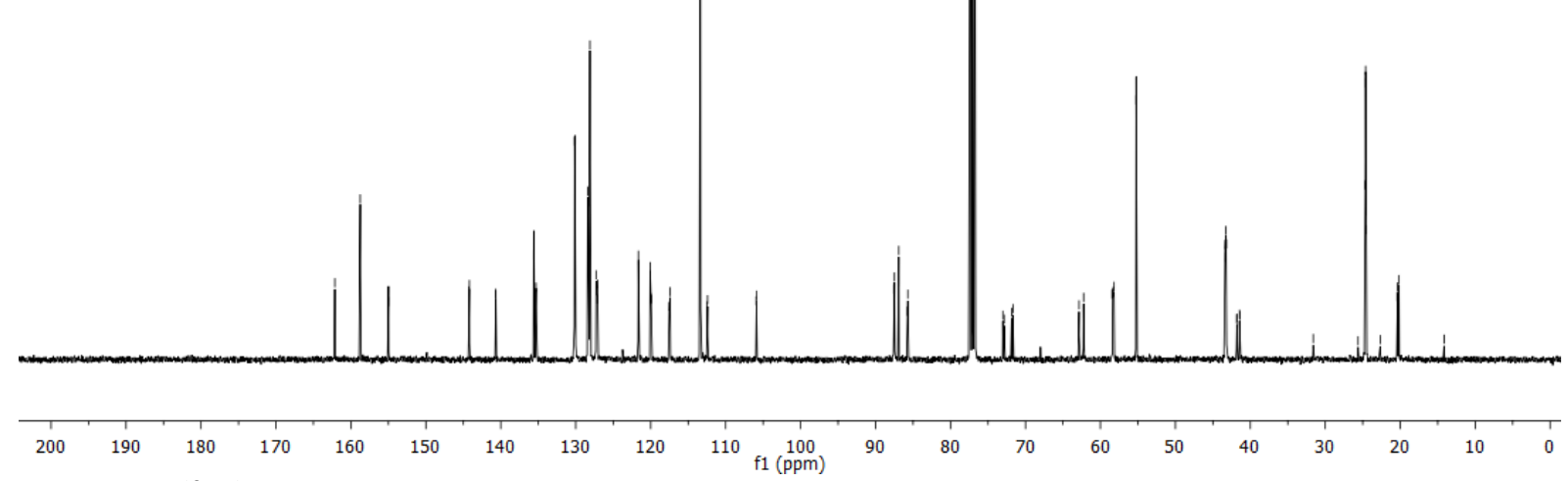

Figure S47. ${ }^{13} \mathrm{C}\left\{{ }^{1} \mathrm{H}\right\}-\mathrm{NMR}$ spectrum of 27 in $\mathrm{CDCl}_{3}$ at $101 \mathrm{MHz}$. 

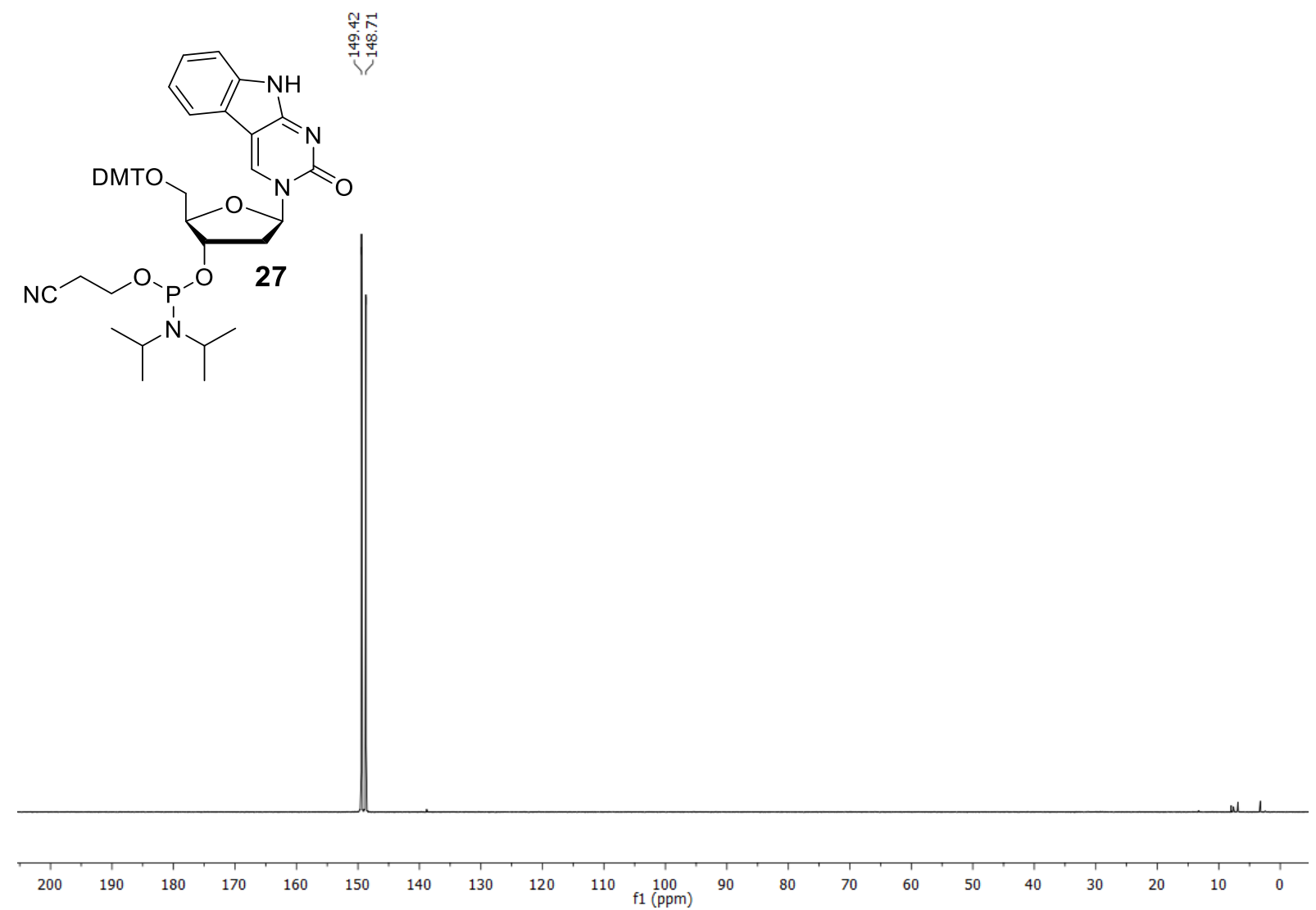

Figure S48. ${ }^{31} \mathrm{P}-\mathrm{NMR}$ spectrum of 27 in $\mathrm{CDCl}_{3}$ at $162 \mathrm{MHz}$. 
Models of $\dot{C}$-labeled DNA and Ċm-labeled RNA

A

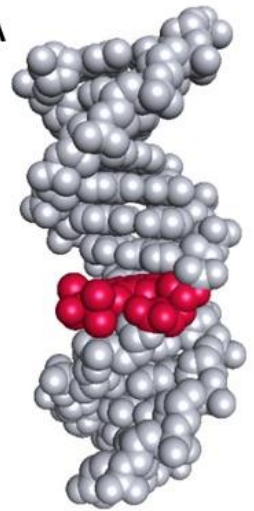

B

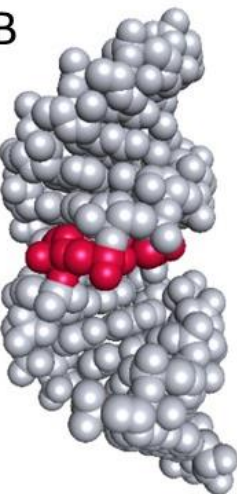

Figure S49. Space-filling models of $\dot{\mathbf{C}}$ - and $\dot{\mathbf{C}} \mathbf{m}$-labeled oligonucleotide duplexes. A. B-form DNA duplex with $\dot{\mathbf{C}}$ projected into the major groove. B. A-form RNA duplex containing $\dot{\mathbf{C}}$. The spin-labeled nucleotides are shown in pink. Modeling of the spin labels inside the duplexes was performed with the following software: BIOVIA, Dassault Systèmes, Discovery Studio Visualizer, v16.1.0.15350, San Diego: Dassault Systèmes, 2016. 
CW-EPR spectra of spin-labeled oligonucleotides
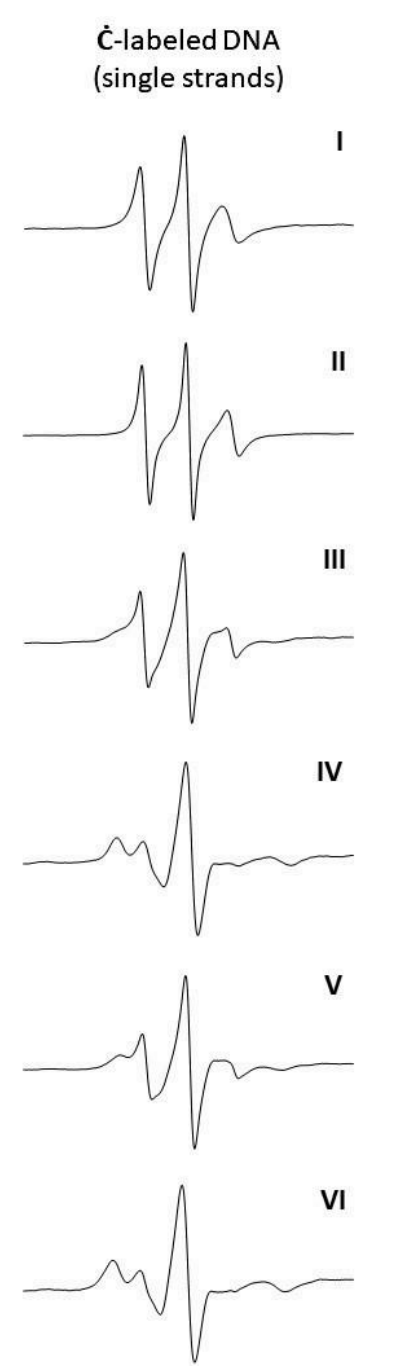

VI
Ć-labeled DNA (duplexes)
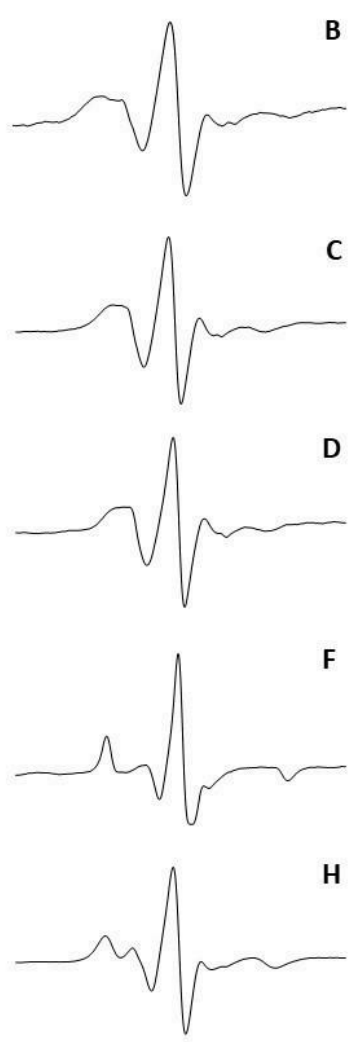

Figure S50. EPR spectra of spin-labeled oligonucleotides.

$$
\begin{aligned}
& \text { Ċm-labeled RNA } \\
& \text { (single strands) }
\end{aligned}
$$

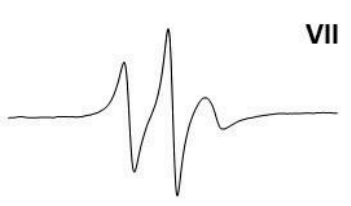

C
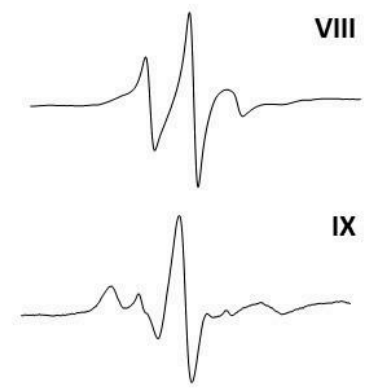

IX
Ċm-labeled RNA (duplexes)
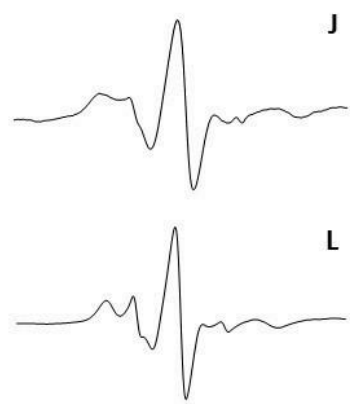
HPLC analyses of enzymatic digests
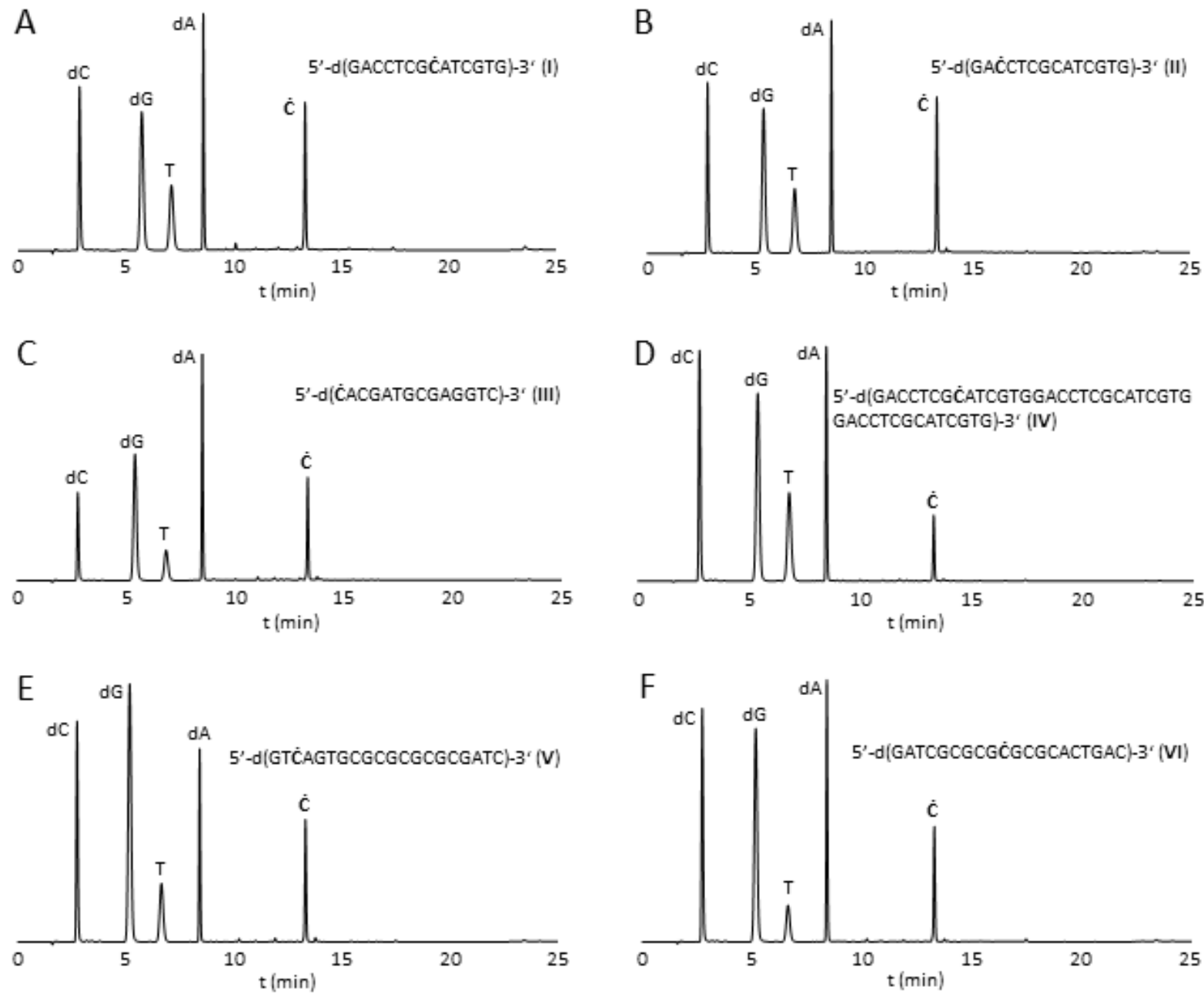

Figure S51. HPLC chromatograms of DNA oligonucleotides after enzymatic digestion with snake venom phosphodiesterase, nuclease $\mathrm{P} 1$, and alkaline phosphatase. ${ }^{1-2}$ 

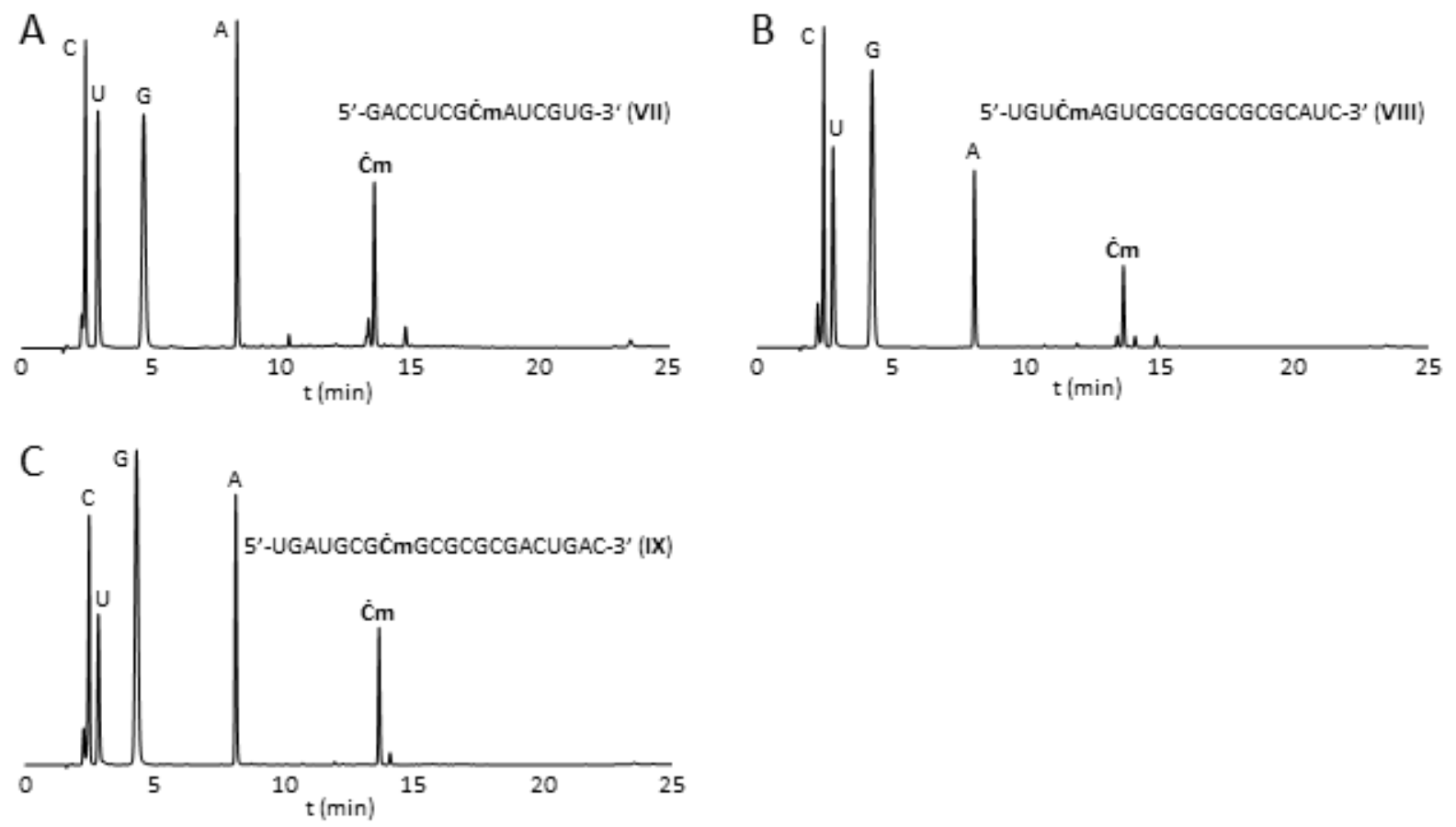

Figure S52. HPLC chromatograms of RNA oligonucleotides after enzymatic digestion with snake venom phosphodiesterase, nuclease $\mathrm{P} 1$, and alkaline phosphatase. ${ }^{1-2}$ 
Thermal denaturation curves of spin-labeled oligonucleotide duplexes
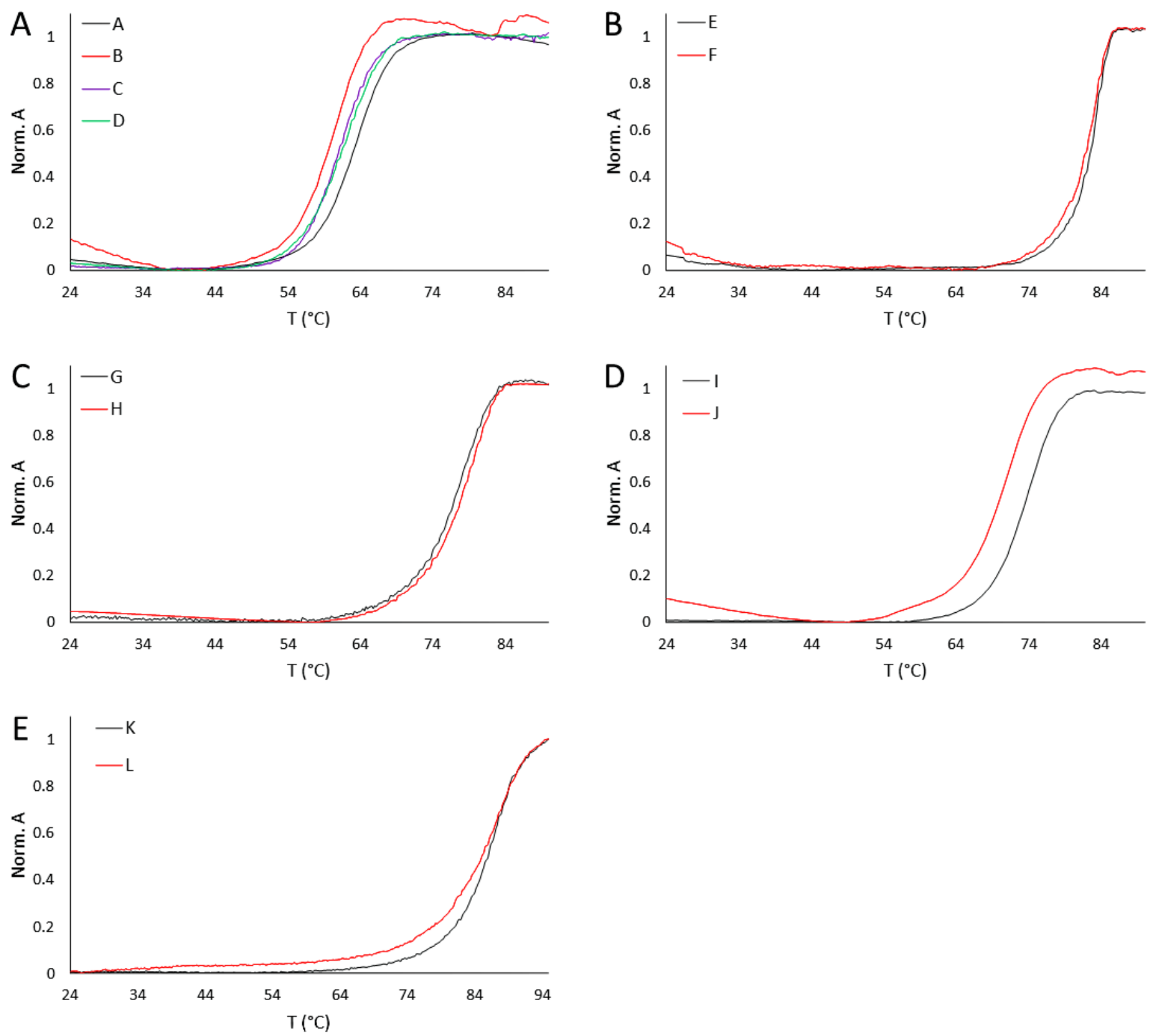

Figure S53. Thermal denaturing analysis of duplexes A, B, C, D (A); E, F (B); G, H (C); I, J (D); K, L (E). 
CD spectra of oligonucleotide duplexes
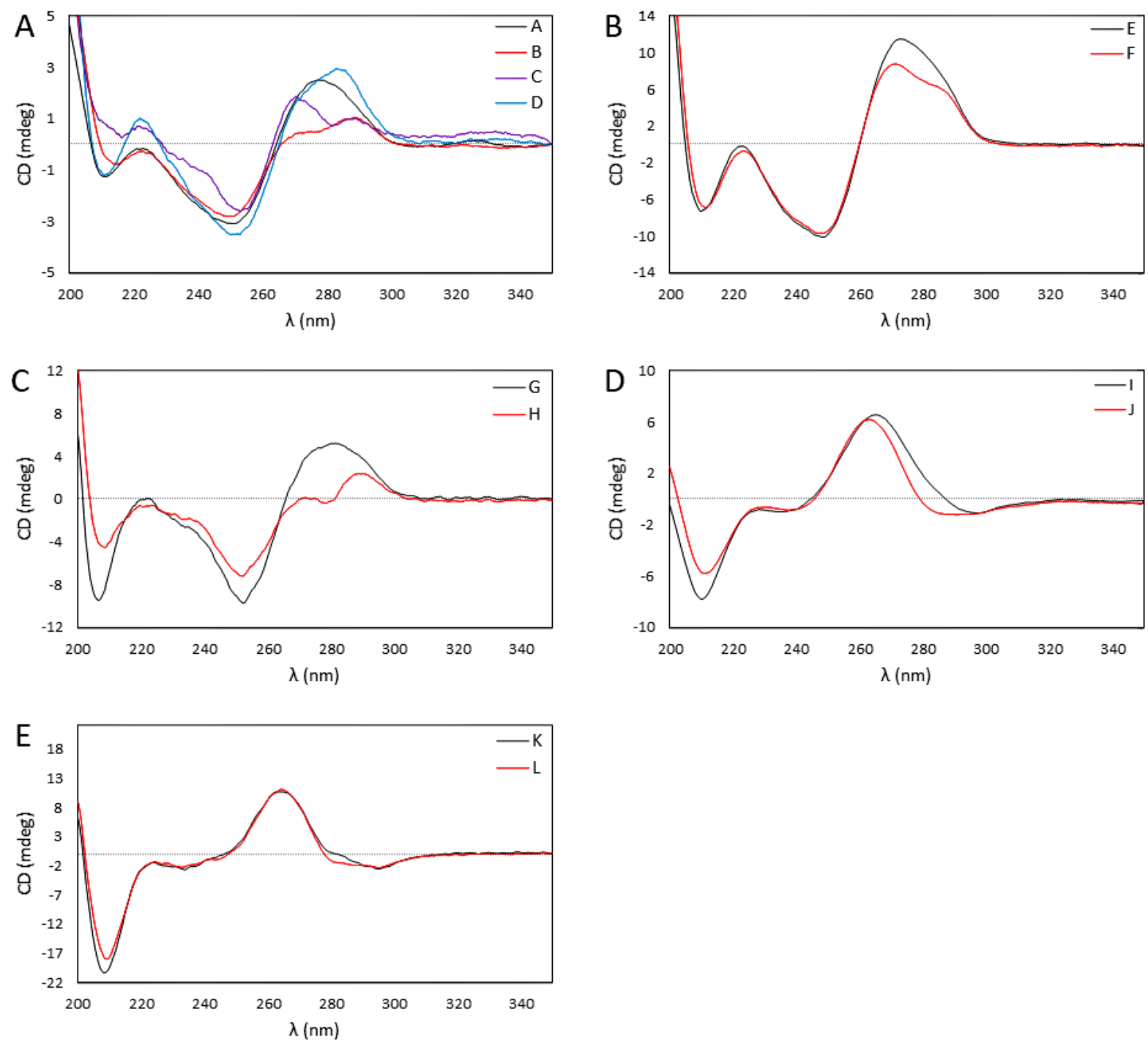

Figure S54. CD spectra of duplexes A, B, C, D (A); E, F (B); G, H (C); I, J (D); K, L (E). 


\section{References}

1. Juliusson, H. Y.; Segler, A.-L. J.; Sigurdsson, S. T., Benzoyl-protected hydroxylamines for improved chemical synthesis of oligonucleotides containing nitroxide spin labels. Eur. J. Org. Chem. 2019, 2019 (23), 3799-3805.

2. Cekan, P.; Smith, A. L.; Barhate, N.; Robinson, B. H.; Sigurdsson, S. T., Rigid spin-labeled nucleoside Ç: a nonperturbing EPR probe of nucleic acid conformation. Nucleic Acids Res. 2008, 36 (18), 5946-5954. 